\title{
JUDICIAL RELIEF FOR INSECURITY
}

In an earlier article ${ }^{1}$ an attempt was made to criticize the narrowness of view which has limited the concept of "wrongs" and "cause of action" to committed delicts, and the concept of the judicial process, to their redress. This superficial view of legal relations and of the judicial function has obscured realization of the fact that harm is done and rights are impaired or jeopardized by mere dispute or challenge before and without any physical attack. The mere existence of an instrument, the denial of a right, the assertion of an unfounded claim, the existence of conflicting claims to the same property or right, the uncertainty and insecurity occasioned by new events-these phenomena constitute the operative facts, the cause for action which creates the plaintiff's "right of action." The term "cause of action" has become so involved in description and definition that it may be profitable to adopt instead the continental criterion of the conditions under which judicial relief may be invoked, namely, whether the petitioner has a "legal interest" in such judicial protection-that is to say, whether his rights have been denied, challenged, or jeopardized by person or event in such way as to justify him in invoking judicial protection for their vindication.

Experience of the past is the most helpful criterion of such "legal interest" or "cause for action." The use of such a guide would have made it readily apparent that a debtor has as much interest in denying the unfounded demand of his creditor as the creditor has in asserting his claim against the debtor. It would have indicated at once that the defeat and denial of any unfounded claim which disturbs or renders insecure a person's rights, whether of status or property, is as much an interest capable of and in need of judicial protection as the assertion of the claim itself. The use of such a criterion might have avoided the mechanistic view of what is a "wrong" and would have made it clear either that the conception of a committed "wrong" is too narrow a requirement of judicial relief or else that any challenge or cloud upon a person's rights is a "wrong" or disturbance which might, by unsettling his security or vested rights, endow him with the power of invoking judicial relief. It would have avoided the verbal difficulty in which the English courts found themselves when they admitted that the Guaranty Trust Co. could sue Hannay \& Co. ${ }^{2}$ for a judgment that it was under no duty to return money demanded by Hannay, paid over

: Judicial Relief for Peril and Insecurity (1932) 45 FIARv. L. REv. 793.

${ }^{2}$ Guaranty Trust Co. of New York v. Hannay \& Co., [1915] 2 K. B. 536. 
under a mistaken assumption that certain bills of lading were genuine and not forged-while at the same time suggesting that the "cause of action" in the "proper sense" lay in Hannay \& Co. and not in the Guaranty Trust Co. The truth is that both parties had a "cause of action" or "legal interest" in a decision and either one cotld have commenced the suit. It is quite immaterial whether the suit is brought by the creditor for the amount of the claim or by the debtor for a judgment that the creditor has no claim. ${ }^{3}$ It is the duty of the court in each case to examine whether the interests of the petitioner are affected by the issue raised in such a way as to justify the court in relieving his predicament. That examination should not be predetermined by rigid conceptions of committed "wrongs," a view which in any event has long ceased to respond to reality: as witness the equitable bill for the removal of clouds from title, for the declaration of the nullity of void contracts or marriages, for interpleader and other remedies the only effect of which is a judicial declaration of the pre-existing rights of the parties and the clarification of their legal relations. Greater emphasis upon the need of the petitioner or plaintiff for an assurance or certification of his rights, and an effort to determine the circumstances under which such need arises, would bring into clearer relief the function performed and performable by courts.

The vindication of assailed or challenged rights, the clarification and stabilization of unsettled legal relations, the removal of clouds on rights, creating peril, insecurity, fears, and doubts-in short, the establishment of social peace in the community, without the necessity for prior violence, is the primary judicial function. The execution of the judgment is only an ancillary and often unnecessary incident. ${ }^{4}$ The belief that the destruction of the status quo is a condition of a justiciable issue is erroneous. It never did correspond fully to the facts, although the definition of "cause of action" seemed to assume it. That it has been definitely abandoned is evidenced by the fact that by statistical count two-thirds of the cases in the Chancery Reports in England come up on an originating summons for a declaratory judgment, which places in issue for conclusive determination a contested legal right. Where such judgment will serve a useful purpose in clarifying a legal

${ }^{3}$ See Fidelity Nat. Bank \& Trust Co. of Kansas City v. Swope, 274 U. S. 123, 131,47 Sup. Ct. 511,514 (1927): "That the issues thus raised and judicially determined would constitute a case or controversy if raised and determined in a suit brought by the taxpayer to enjoin further proceedings under the ordinance could not fairly be questioned. Compare Risty v. Chicago, R. I. \& Pac. Ry. Co., $270 \mathrm{U}$. S. 378. They cannot be deemed any the less so because through a modified procedure the parties are reversed and the same issues are raised and finally determined at the behest of the city."

Nashville, Chattanooga \& St. Louis Ry. v. Wallace, 53 Sup. Ct. 345 (1933), and cases there cited. 
relation, its grant evidences the essence of judicial power and civilized administration, a function performed before one or the other party has acted on his own interpretation of his rights and has perhaps irretrievably destroyed the disputed economic and social relations. The function is the more necessary in a period characterized by long-term contracts and property relationships, yet subject to rapid change by statute or other event creating a new situation not in the original contemplation of the parties.

In the article mentioned above, some attempt was made to illustrate the utility of the action for a declaration in certain types of legal relations in which the plaintiff seeks to avoid the risks of error or disaster by suing an adversary in interest for the declaration of a privilege or immunity before acting on his own view of his rights. Thts, he has been enabled to determine whether he was legally justified in his asserted claim that by a change of circumstance he is now relieved of an obligation ostensibly still binding, or that he is privileged to act without danger of penalty, forfeiture, or prejudice, as threatened by the defenclant. The removal of the cloud from his claimed privileges and immunities clarifies the rights of all parties concerned; and it has proved to be immaterial which of the two contestants initiates the action. Citizens and administrative officers in adversary positions have thus been enabled to clarify their respective privileges and immunities in the speediest form, permitting the process of government and administration to proceed with the least friction and delay, while avoiding the consequences of a mistaken course. The issue is raised before rather than after the challenged step is taken; the litigant can look before he leaps rather than risk having to pick up the pieces after a leap in the dark.5

Not the least of the advantages of the action for a judicial declaration of rights over coercive forms of procedure is the possibility of adjudicating disputes on issues of law in simple, civilized fashion without violence or breach of economic and social relations. Legal positions can be effectively asserted, yet without that cocksureness that makes defeat huimiliating. Honest doubt may be admitted without sacrifice of position, where certainty is often a pretense and the setting histrionic. The respective arguments for declaratory judgment may be as earnest as the trial by court battle is often vitriolic. No one can read the English Chancery Reports without appreciating that all parties to the judicial proceedings for a declaration of rights appear to remain gentlemen ard

"The repetition of Representative Gilbert's (Ky.) remark may be pardoned: "Under the present law you take a step in the dark and then turn on the light to sce if you have stepped into a hole. Under the declaratory judlgment law you turn on the light and then take the step." 69 CoNG. Rec. 2108 (1928). The Federal Declaratory Judgments Bill, H. R. 4624, was unanimously passed (for the third time) by the House of Representatives on Dec. 19, 1932. 
that it is possible for people to have differences as to legal rights without becoming enemies. Where the milder form of relief by judicial declaration will serve the plaintiff's purpose and terminate the issue, it seems crude to require him to demand a coercive levy on the defendant as proof of his need for judicial protection. Flexibility of procedure and in prayers for relief is essential to efficient.administration; and it ought to be evident from the cases already discussed and hereafter examined that individual and social needs are in many cases adequately and more effectively subserved by a mere declaration of rights than they could be by any more vigorous and belligerent judgments. In the present study attention will be directed primarily to a series of fact situations in which the plaintiff seeks to stabilize and render secure his legal position, placed in doubt or uncertainty by some act or position taken by the defendant. He thereby attains an assurance of his present and future rights, which otherwise would remain in continued jeopardy, with all its consequences. This possibility of removing clouds from rights, thus establishing present rights to future enjoyment, is one of the most useful social functions which courts can perform.

\section{Vindication of Present Rights, To Prevent Future Injury or Disadvantage by Failure of Timely Assertion}

One of the commonest needs of a person claiming a right is to prevent its loss or dissipation by the happening of future contingencies, including the lapse of time. It also becomes frequently necessary to safeguard an existing right, even though its exercise may have to be postponed until further facts have become established, or notwithstanding the fact that a condition precedent has not been literally fulfilled. There may often be sound reasons, moreover, to prefer at the moment a declaration over more drastic action-action which may indeed become unnecessary if it is possible to preserve a claimed right against impairment or loss by present assertion and judicial confirmation. Illustrations. of these various manifestations of the demand for security by declaration may be of interest.

A claimant or creditor may desire to assert his right presently, because by waiting he may lose his security or because the statute of limitations may run against him. Thus, a mortgagee of licensed premises in Ireland, on which a liquor license was the principal security, sued for a declaration of the right to possession before the lapse of the license year, because the debtor's failure to keep the premises open endangered the license and hence the creditor's security. ${ }^{6} \mathrm{~A}$ serious danger that the

${ }^{\circ}$ Doran v. Hannin, 40 Ir. L.T. R. 186 (1906) (also included decree for delivery of possession under Order 55, rule 7, like English Order 55, rule 5A). 
claim would be lost by prescription has justified the assertion and declaration of the existence of the claim, especially if for some reason the creditor preferred not to or was unable to press it effectively at the time, ${ }^{7}$ for example, where an injury has been done resulting in damage, but considerable time must elapse before the exact amount of the damage can be determined. Under such circumstances the courts have sustained the propriety of suing for a declaration of the defendant's liability (duty to pay), leaving open to future accounting the amount of the damage. ${ }^{8}$ So, it may often be important presently to establish the defendant's liability, although the amount thereof will depend upon the amount that the plaintiff himself, surety or co-contractor, may have to pay in the future to third persons. ${ }^{9}$ Again, a plaintiff may seek by declaration to protect his claim against an intimated or threatened defense of the running of the statute of limitations, by a demand for a declaration that a given act, such as the publication of a balance sheet, is an acknowledgment of the debt. ${ }^{10}$ The issue is thus narrowed to

'In re Lister, Ex parte Bradford Overseers, [1926] Ch. 149 (town sues to establish defendant receiver's liability for taxes due from bankrupt estate; declaration that defendant was not personally liable, and declaring source of payment); In re Wiits \& Somerset Farmers, Itd., [1928] Ch. 809 (liquidator sues to establish status as subscribers, members, or contributors, which determines extent of their liability to contribute); $R G$. June 24, 1907, Soergel 1907, 604 (right of action against a surety was conditioned upon unsuccessful recourse against principal debtor; on proof that latter was without means, declaratory action to establish liability of surety, that is, existence of the necessary condition, was sustained); RG. Nov. 25, 1910, Soergel 1911, 581 (judgment for declaration of defendant's liability, where prompt calculation of the amount of damages would now be difficult) ; Hamburg, Jan. 9, 1911, Soergel 1911, 581; RG. Feb. 24, 1914, Soergel 1914, 498; RG. May 11, 1925, Soergel 1926, 306; RG. Jan. 27, 1927, Soergel 1927, 302; RG. 101, 135, Dec. 18, 1920 (action for declaration, combined with injunction and damages, that defendant by selling certain powders was violating plaintiff's patent: "It is sufficient for a declaration if there are acts which evidence the intention to violate plaintiff's patent rights, so that there is cause for fear or danger") ; see also RG. 95, 304, April 13, 1919. But in RG. 94, 227, Dec. 2, 1918, the plaintiff was merely in doubt as to whether the statute of limitations would run against her; the declaration was denied because there was no evidence of danger or threat that it would run, but only of plaintiff's doubt as to the applicable rule of law. See Haldane v. Haldane, [1921] N. Z. 612, action to enforce a parole agreement for maintenance during plaintiff's life and to secure certain personal property alleged to belong to her. Said the court: "I shall merely declare, therefore, that the plaintiff is entitled to recover... and I refer the matter to the Registrar" for identification and description of the articles in question.

${ }^{8} \mathrm{RG} .23,347$, Feb. 18, 1889 ("The plaintiff is interested in the simplicity of the proceeding. It is appropriate to specify the damages already sustained and a claim for future damages in one proceeding"); Oberverwaltungsgericht Saxony 17 OVG. 246, July 20, 1911, Soergel, Jahrb. d. Verwaltungsrechts V, 473 (declaration of rights proper, to prevent repetition of the litigation and where delay of decision might be prejudicial to the dispute); Breslau, OLG. Nov. 28, 1910, Soergel 1911,581 . (1923).

A. E. Joy Co. v. New Amsterdam Casualty Co., 98 Conn. 794, 120 At1. 684

${ }^{10}$ In re Atlantic \& Pac. Fibre Importing \& Mfg. Co., Viscount Burnham v. The Company, [1928] Ch. 836 (the plaintiffs were owners of the defendant company's debentures, on which interest had been unpaid for some years; to keep their 
the point whether the statute of limitations has run. In all these cases a claimant having a right which is placed in jeopardy by force of circumstances or by the act of the defendant seeks a declaration which preserves or safeguards the right, without necessarily pursuing it to execution, in some cases because it cannot be then executed, in others because-he prefers not to attempt to execute it but finds sufficient protection in a declaration of its existence.

\section{Assertions of Lien or Clain}

Creditors, including mortgagees and unpaid vendors ${ }^{11}$ or suppliers of materials, ${ }^{12}$ in order to safeguard their rights against impairment

claim alive against an intimation that it had lapsed, the plaintiffs sued for and obtained a declaration that publication of the defendant's balance sheet was an admission of the claim, and removed the bar of the statute of limitations) ; RG. 100, 149, Oct. 19, 1920 (plaintiff seeks declaration now of defendant state's no-right to exact further tax, because statute of limitations would later bar the "claim of immunity).

II Bard v. Standard Mtge. Corp., 119 Cal. App. 509, 6 P. (2d) 582 (1932); Malone v. Romano, 95 N. J. Eq. 291, 127 Atl. 91 (1923); Everts v. Kepler, 9 D. \& C. 439 ( $\mathrm{Pa}$. 1927). (Plaintiff, judgment creditor, sues for declaration that defendant, his debtor, has a fee under a will, and that judgment is valid against son's property. It might also have been a spendthrift trust, in which case levy would have been invalid. Declaration was a necessary precaution against error.); West Ham Corp. v. Sharp, [1907] 1 K. B. 445; In re Harris Calculating Machine Co., Sumner v. The Company, [1914] $1 \mathrm{Ch}$. 920 (plaintiff, debenture holder, who had advanced money to pay defendant company's overdraft, on agreement to repay under certain conditions, claims declaration that his claim constitutes first charge on company's assets); In re Farnol Eades Irvine \& Co., [1915] 1 Ch. 22; James Roscoe (Bolton), Ltd. v. Winder, [1915] 1 Ch. 62; In re Law Guarantee Trust and Accident Soc., Godson's Claim, [1915] 1 Ch. 340 (plaintiff, debenture holder, sues trustee-guarantor of issuing company's debentures in default, for declaration that he is entitled to benefit of reinsurance effected by defendant guarantor, of which plaintiff at time of acquisition was unaware); In re Iamplugh Iron Co., [1927] 1 Ch. 308 (plaintiff, director and holder of corporate debenture, guaranteed and then paid certain company taxes and on liquidation claims a declaration of priority of his claim); Beamish v. Whitney, [1908] 1 Ir. R. 38; Wallace v. Fogarty, [1926] Ir. R. 255; Butler v. Butler, [1925] 1 Ir. R. 185; Northern Banking Co. v. Carpenter, [1931] Ir. R. 268 (pledgee of deeds claims equitable mortgage); National Bank v. M'Govern, [1931] Ir. R. 368; Anderson v. Moran, 23 Alta. L.R. 474 (1928); National Discount Corp. v. Frech, [1928] 2 D. L.R. (Ont.) 256; Sakaliuk v. Corry, [1930] 2 D. L. R. (Aita.) 239 ; Graham v. Hammill, 35 Manit. L. R. 510 (1926); Smith v. Cunningham, 34 N. Z. 385 (1915); Branigan v. Official Assignee of Branigan, [1926] N.Z. 423; Bank of New Zealand v. Baker, [1926] N.Z. 462; RG. 27, 204, Nov. 5, 1890 (creditor, attaching a debt owed by defendant $A$ to plaintiff's debtor $B$, seeks by declaration to establish existence of the debt, thus preventing $A$ from paying it to $B$, in disregard of plaintiff's rights; debt presumably not yet due). See also Tom v. Trustees of Hans C. Christensen, Ltd., 40 B. C. 124, 383 (1928); RG. Sept. 30, 1911, Soergel $1912,494$.

${ }_{12}$ Sunderland Corp. v. Priestman, [1927] 2 Ch. 107 (city claims declaration that repairs made by it are a lien on defendant's property); Paddington Borough Council v. Finucane, [1928] Ch. 567 ; Byron Hall, Ltd. v. Hamilton, 45 C. L. R. 37 (1930) (that plaintiffs, who had built apartment houses on defendants' land under agreement to receive title for stock in plaintiff corporation, had a lien on the land for expenditures made); Hutchinson v. Berridge, 18 Alta. L. R. 121 (1922) (lien on defendant's interest in certain property); Cunningham v. Sigfusson, [1928] 1 D. L. R. (Sask.) 726; Freedman v. Guaranty Trust Co., [1929] 4 D. L. R. (Ont.) 32; Brookfield Bros., Ltd. v. Shafer, [1930] 2 D. L. R. (Nova Scotia) 137, rev'g, [1929] 4 D. L. R. 638; Brown v. Associated British Motors, [1932] N.Z. 655. 
often seek a declaration of the existence of a lien in their favor. So, a vendee may seek a declaration that, where the vendor failed to deliver, because of his bankruptcy, fire or other cause, the vendee has a lien for the money paid ${ }^{13}$ or on the insurance recovered by the vendor. ${ }^{14}$

Again, a creditor, observing that his debtor has assigned an asset to which he had looked as security for his claim, may seek at once a declaration that the assignment is void as in fraud or defiance of his rights. ${ }^{15}$ So, a claimant against a bankrupt estate may, in case his claim is disputed by the receiver, establish by declaration that he is a creditor, as well as the amount of his claim. ${ }^{10}$ Mortgage bondholders, fearing that debtors or trustees may take steps calculated to disturb their liens or security, achieve as useful and a more speedy result by suing for a declaration of the invalidity of the proposed or threatened step rather than for an injunction. ${ }^{17}$

An owner of property or a claimant of rights therein may sue for a declaration that a defendant, who has already interfered with or is about to impair or interfere with his right by asserting an adverse claim, has no-right to disturb the plaintiff's title, ${ }^{18}$ a decision which may

${ }^{13}$ In re Wait (C. A.) [1927] $1 \mathrm{Ch} .606$ (bankruptcy of vendor-suit by stubpurchaser of $c$. i. f. buyer who had resold, received payment but had not delivered goods, pledged bills of lading, and then went into bankruptcy, against trustec in bankruptcy, either for specific performance, return of purchase price, or declaration that plaintiffs had beneficial interest in goods and lien on bills of lading). But cf. Waddell v. Gray-Campbell, Itd., [1929] 2 D. L. R. (Sask.) 362.

${ }^{14}$ Brownell v. Board of Education of Saratoga Springs, 239 N. Y. 369, 146 N. E. 630 (1925). (In the alternative vendee sued for specific performance and application of insurance on purchase price; defendant offered to return down payments and rescind. Held, insturance belongs to vendor, but not in trust for vendee, who may rescind or sue for damages.)

${ }^{15}$ Semenowich v. Melnyk, 93 N. J. Eq. 67, 115 Atl. 41 (1921); Skogman v. Ellergodt, [1929] 4 D. L.R. (Alta.) 710; Cameron v. Mosely, 56 Nova Scotia 300 (1923) (judgment creditor seeks declaration that conveyance by debtor is void); In re Hume, 28 N.Z. 793 (1909); In re Bell, 33 N.Z. 154 (1913); Official Assignee of Reeves v. Paterson, [1918] N.Z. 623; RG. 33, 312, July 12, 1894 (pledgee of a claim, taken as security, sues assignec of same claim that his assignment is simulated and invalid and that her pledge has priority); RG. 35, 95, July 21, 1895. See cases infra note 43 , for declarations sought by creditors or receivers that transfers constituted fraudulent preferences.

${ }^{16}$ Anstee v. Spring, 32 N. Z. 966 (1913); In re Hamilton \& Co., Hamilton \& Co. v. Overell \& Sampson Proprietary, [1924] N. Z. 386.

${ }^{17}$ Commonwealth Life Ins. Co. v. Lotuisville Ry. Co., 234 Ky. 802,29 S. W. (2d) 552 (1930) (refinancing proposal, which would release liens of three mortgages and postpone for five years maturity of the bonds; held, for defendant).

${ }_{13}$ Ohio-Kentucky Coal Co. v. Auxier, 239 Ky. 442, 39 S. W.(2d) 662 (1931) (defendant lessee claimed option to purchase mineral rights against stubsequent vendee of land and the rights); Village of Grosse Pointe Shores v. Ayres, 284 Mich. 58, 235 N. W. 829 (1931) (that conditions placed upon plaintiff in deed of land to be used for boulevard purposes, were void); Calvary Presbyterian Church v. Putnam, 249 N. Y. 111, 162 N. E. 601 (1928) (Suit against living heirs of persons who had quitclaimed to plaintiff 35 years ago, and covenanted not to interfere with plaintiff's use of the property, for declaration that its title and right to use were unimpaired, because no possibility of reverter. Suit for quieting title, induced by plaintiff's doubt and fear); Whalen v. Strong, 230 App. Div. 617, 246 . 
depend upon the interpretation of a contract or statute. So, a plaintiff, instead of suing in ejectment or trespassing on property or taking some drastic step to vindicate his right, may find adequate satisfaction and relief for his disputed claim by suing for the judicial declaration of his interest or of his right to enjoy it. ${ }^{19}$ The necessity for such declaration may arise because new circumstances have cast doubt and uncertainty upon former relations.

So, an owner in possession may seek by declaration to remove a cloud upon his title created by some document in defendant's control or

N. Y. Supp, 40 (4th Dept. 1930) ; Johnson's Estate, 15 D. \& C. 347 (Pa. 1930); Waller v. Sproles, 160 Tenn. 11, 22 S. W. (2d) 4 (1929); Crichton v. Crichton, 43 C.L. R. 536 (1930) (that by deposit of certain bonds for defendant in defendant bank, plaintiff had not established a trust and was still the owner; held, for defendant); Mauch v. National Securities, Ltd., 14 Alta. L. R. 531 (1919) (plaintiff gave $X$ his certificate of title for purpose of registration; $X$ pledged it, however, as security and defendant became bona fide purchaser; held, title in defendant) [cf. Eliason v. Wilborn, 281 U. S. 457, 50 Sup. Ct. 382 (1930) (petition under Illinois torrens act for cancellation of deeds and certificate of title)]; Wekusko Mines, Ltd. v. May, 36 Manitoba L. R. 351 (1927) ; Williamson v. Auckland Hosp. \& Charitable Board, 33 N. Z. 1048 (1914); RG. 27, 204, Nov. 5, 1890 (plaintiff seeks declaration of his co-ownership in real estate, which had been sold at public auction. "As a rule, a declaration cannot be based on a past relation. But there. is an exception where, as in this case, the former existence of a legal relation forms the basis for a present claim"); RG. May 23, 1908, Soergel 1908, 491; OLG. Dresden, Nov. 6, 1908, Soergel 1909, 561. Cf. Conemaugh Iron Works Co. v. Delano Coal Co., $298 \mathrm{~Pa}$. 182, 148 Atl. 94 (1929), plaintiff unsuccessfully sought to enjoin defendant from enforcing judgment on plaintiff's property, on ground that issue was under trial on the law side. Property was sold to plaintiff by $B$ Co., and plaintiff had placed mortgage on it to protect $B$ Co.'s bondholders. $B$ Co. was debtor of defendant, who claimed that conveyance to plaintiff had been in fraud of creditors. Said the court: "The status of the mortgage and the rights of the mortgagees car be determined in proceedings under the Declaratory Judgment Act, with all parties in interest on record." Cf. also Kraft's Appeal, 303 Pa. 1, 154 Atl. 19 (1931).

${ }^{20}$ Laughlin v. Neeley's Ex'x, $223 \mathrm{Ky}$. 656, 4 S. W. (2d) 690 (1928) (Residuary legatee claims absolute estate, against defendant's claim of defeasible estate if he "dies without descendants." Held, for defendant) ; City of Paducah v. Mallory, 225 Ky. 692, 9 S. W.(2d) 1015 (1928) ; Reid v. Rèid, 230 Ky. 835, 20 S. W. (2d) 1015 (1929); Mayor, etc., of London v. Horner, 111 L.T.R. 512 (1914) (that plaintiffs had right to enter on market, which right defendant claims has been lost by estoppel) ; St. Catharine's College, Cambridge v. Rosse, [1916] 1 Ch. 73 (plaintiff asserts right under statute to subsoil minerals under defendant's land); In re Blyth Shipbldg. and Dry Docks Co., Forster v. The Company, [1926] Ch. 494 (debenture holders in defendant company, now bankrupt, sue for declaration as to who owns incompleted ship and materials built by defendant for Italian company, but which could not be delivered because of the bankruptcy); Mainka v. Custodian of Expropriated Property, 34 C. L. R. 297 (1924); Colonial Sugar Refining Co. v. Melbourne Harbour Trust Comm'rs, 36 C. L. R. 230 (1925); 38 C.L.R. 547 (P.C. 1927); Tooley v. Hadwen, 13 Alta. I. R. 447 (1918) (that plaintiff has good title, with loss of which he is threatened, notwithstanding his own violation of a time clause in his deed); McLeod v. McLeod, 24 Alta. L. R. 565 (1929) ; Turnbull v. Eden, 41 B. C. 381 (1929); Hayes v. Ross, No. 2, [1919] N.Z. 777 (Vendor who was to receive from vendee security for purchase price sues for declaration that thing sold did not below to purchaser, who had become bankrupt, and that he was entitled to rescission. So held.); Erena Pou y. Nicholson, [1923] N.Z. 257. 
by some claim of the defendant. ${ }^{20}$ Similarly, an owner by adverse possession or under a lost deed may claim a declaration of his title. ${ }^{21}$ These are but familiar exemplifications of the tusual bill in equity to quiet title, which has all the characteristics of an action for a judicial declaration.

Very complicated issues involving property, to which different persons lay a variety of claims, are frequently determinable in one simple declaratory proceeding in which they are all made parties. Thus, in Re Cryan's Estate, ${ }^{22}$ plaintiff sought a declaration of interest taken in realty given under a will, because she wished to borrow money to make repairs and to meet a mortgage which was about to mature. Plaintiff, as executrix and beneficiary, claimed either a fee or a joint fee with a sister but had never taken possession of the property. The children of a deceased devisee claimed a vested interest, because of which the plaintiff could not secure a loan. Plaintiff did not wish to sue for partition, because none of the parties desired to sell; there was no surplus to distribute, so she could not file an accounting; and defendant not being in possession, she could not bring ejectment. The declaration clarified the position. In Gruntal v. United States F. \& G. Co., ${ }^{23}$ plaintiff stockbrokers had received bonds from defendants. It was later discovered that they were stolen bonds and the brokers had to replace them for their customers. Plaintiffs sought a declaratory judgment of their title in the bonds, claiming that they had had an interest in them and now had title, whereas defendant surety company claimed that it was the real owner, as it had paid insurance to the real owners and had been subrogated to their rights. The insecurity and uncertainty

${ }^{20}$ Duncan v. Mason, 239 Ky. 570, 39 S. W. (2d) 1006 (1931) (that defendants had, by abandonment and non-use, lost their right to mine under deed); Troffo $v$. Camione, 16 D. \& C. 92 (Pa. 1930) (that defendant's asserted lien is non-existent); In re De Leeuw, Jakens v. Central Advance \& Discount Corp., [1922] 2 Ch. 540 (Legatee seeks to establish that mortgages in defendant's favor and foreclosure decree which defendant had obtained were invalid against plaintiff, because obtained through fraud. So held.); Collister v. Reid, 27 B. C. 278 (1919); Engineer Mining Co. v. Fraser, 31 B.C. 224 (1922); McIntyre v. Haynes, 35 B. C. 40 (1925); In re Brown to the Wanganui Investment Soc., 29 N.Z. 652 (1909) (declaration that mortgage had been released, that the unregistered release had been lost, and that plaintiff entitled to registration as owner free of the mortgage); Chairman, etc., of the County of Kairanga v. Bannister, 33 N. Z. 1184 (1914); Te Aka Pairama v. Hardy, [1918] N. Z. 65, 492 (that plaintiff owner's land was valid); cf. Mathieson v. Hall, [1929] N. Z. 333. In Green v. Riordan, 97 Cal. App. 462,276 Pac. 141 (1929), a vendor who had given a deed sought a declaration that it was in fact a mortgage only. In Semenowich $v$. Melnyk, supra note 15, a grantee whose deed judgment creditors had sought to set aside as ill fraud of creditors filed cross-bill for declaration that it was a mortgage.

${ }^{2}$ Allen v. Folwell, 1 Tenn. App. 515 (1926); [cf. Sharon v. Tucker, 144 U. S. 533, 12 Sup. Ct. 720 (1892) (adverse possession, under traditional procedure)]; Dobek v. Jennings, 23 Alta. L. R. 306 (1927); Cohn v. Cohn, 56 Nova Scotia 289 (1923).

\footnotetext{
$=301 \mathrm{~Pa} .386 .152$ At1. 675 (1930).

${ }^{2} 134$ Misc. 525, 235 N. Y. Supp. 546 (Sup. Ct. 1929).
} 
of many persons were thus relieved before any of them had undertaken irretrievable steps upsetting the status quo.

Not greatly dissimilar are the cases in which one claiming present or future rights in property or benefits flowing therefrom, under contract or otherwise, seeks a declaration of the defendant's no-right to diminish the plaintiff's advantages, thus preserving the status quo against threatened or future impairment.

\section{Priority among Creditors and Lienors.}

The complicated nature of credit and security transactions necessarily brings in its train frequent contests among conflicting creditors seeking to establish the priority of their own claim or lien as against other claims of similar or different type. The contingency calling the conflict into life may be bankruptcy, death, the maturity. of a debt, or some act or event placing the legal relationship of the parties in doubt, such as the attempt of one creditor to foreclose on his security, claim payment, enter judgment, or levy execution against the common debtor.

Thus, a judgment creditor seeking to levy execution may be met by conflicting claims of creditors claiming some interest in the debtor's property, such as a mortgage, which purports to bar the levy. It becomes of importance to dispose of the contested issue of priority, by seeking a declaration of the invalidity or inferiority of the mortgage or conflicting claim. ${ }^{24}$ By clarifying the legal position in advance of rather than after execution, the judgment creditors-and indeed all other interested parties-avoid the unhappy consequences of an improper levy.

On the other hand, mortgagees, met by conflicting claims of prior undisclosed mortgagees or other claimants, may, without undertaking the expense and risk of foreclosure, seek by declaration to assure their lien. ${ }^{25}$ Thus, the holder of a prior unrecorded mortgage finds in the

st English v. First National Bank of Lock Haven, 9 D. \& C. 718 (Pa. 1926) (plaintiff judgment creditor who had started suit before, but did not obtain judgment until after debtor had been adjudged lunatic, seeks declaration against other creditors and lunatic's guardian that plaintiff is entitled to priority against estate of lunatic) ; City Nat. Bank \& Trust Co. of Miami, Fla. v. City of Knoxville, 158 Tenn. 143, 11 S. W.(2d) 853 (1928) (judgment creditor under loan against prior vendee under unregistered deed who had gone into possession); Quinn v. M'Cool, [1929] Ir. R. 620; McCullough v. Marsden Estate, 14 Alta. L. R. 94 (1918) (judgment lien v. mortgage, arising out of alleged subrogation); Marshall Wells Alberta Co. v. Alliance Trust Co., 15 Alta. I. R. 571 (1920) ; Netherlands Investment Co. v. Des Brisay, [1928] 1 D. L. R. (Alta.) 581; Pellat \& Pellat, Ltd., v. McLean, [1929] 3 D. L. R. (Ont.) 82 (that certain mortgages given by defendant to defendant bank were void as against plaintiffs, defendant's creditors) ; Kerschener v. Convention of Baptist Churches, [1930] 4 D. L. R. (B. C.) 135.

${ }^{2}$ A. M. Krantz Co. v. Kort, 109 N. J. Eq. 150, 156 Atl. 662 (1931) (that deed is a mortgage and that plaintiff's rights are not impaired); Moore v. Oyer, 21 Northam. Co. Rep. 345 ( $\mathrm{Pa} .1928$ ) (Controversy arose at a sheriff's sale under the 
declaration a simple method of determining the legal priority of his mortgage over a later but recorded mortgage, either in a suit against the common debtor or against the other mortgagee. ${ }^{26}$

Suits between other types of conflicting claimants to security or priority are not uncommon. Landlords have claimed declarations that their claim for rent has priority over a chattel ${ }^{27}$ or a land mortgage ${ }^{28}$ on the leased premises. So, debenture holders or general creditors or joint claimants to a single fund may sue each other ${ }^{20}$ or mortgagees ${ }^{30}$ for a declaration of the priority of the plaintiff's rights. It is not uncommon for one class of stockholders to sue other classes for the determination of their respective rights to priority in the distribution of capital or income, the issue involving usually the construction of the corporate agreement or articles of association..$^{31}$

Claims to priority are frequently stimulated by receivership or bankruptcy proceedings. The federal courts now, as an incident to the administration of such an estate in receivership, often find it necessary to determine such questions of priority and preference, apparently unaware of the fact that they are thereby rendering declaratory judgments. ${ }^{32}$ In jurisdictions having the advantage of declaratory procedure, such issues are commonly determined by an action for a decla-

plaintiff's second recorded mortgage, third recorded mortgagees claimed that theirs was a purchase money, hence first mortgage. Plaintiff sued to establish priorities. Court approved declaratory judgment on fact of priority "in advance of another sale") ; Hill v. Peters, [1918] 2 Ch. 273; Ipswich Permanent Money Club v. Arthy, [1920] 2 Ch. 257; Anchor Trust Co. v. Bell, [1926] Ch. 805; Bank of Hamilton v. Hartery, 25 B. C. 150 (1917) (that plaintiff's mortgage had priority over defendant's judgment); Gordon v. Snelgrove, [1932] 2 D. L. R. (Ont.) 300; Carson v. Fraser, [1919] N. Z. 53.

${ }_{23}$ Ini re Monolithic BIdg. Co., Tacon v. The Company, [1915] 1 Ch. 643.

27 Poole v. Kirk, 53 Ont. L. R. 390 (1923) (Landlord had distrained X's goods for rent, but had agreed to leave $X$ in possession. Defendant had chattel mortgage on goods and had warrant for seizure issued. Then landlord sued for declaration of priority).

${ }^{2}$ Aotea Dist., Maori Land Board v. State Advances Supt., [1928] N.Z. 1 (plaintiff was lessor, defendant held mortgage from lessee. Lessec abandoned, owing rent and plaintiff re-entered. Plaintiff called for new tenders for lease, claiming that unpaid rent was first charge as against defendant's claim of priority of mortgage.).

${ }_{\approx}$ In re Automatic Bottle Makers, Osborne v. Same, [1926] Ch. 412 (secured creditor claiming rights of one set of debenture holders against holders of other series); Clydesdale Bank v. Walker \& Bain, [1926] Scot. S. C. 72 (that sale by plaintiff mortgagees of ship was valid, notwithstanding arrest of ship by defendant on sale date, and that plaintifis privileged to retain sum received to satisfy mortgage) ; RG. 98, 143 (1920); RG. May 4, 1909, Soergel 1909, 555; RG. June 3, 1910 , Nos. 2606 and 2607, Soergel 1910, 509.

${ }_{30}$ In re Rogerstone Brick and Stone Co., Southall v. Wescomb, [1919] $1 \mathrm{Ch}$. 110 (plaintiff holder of debentures seeks declaration that debenture holders entitled to have proceeds of sale of property applied to extinction of debentures in priority to mortgage).

${ }_{31}$ De Vail v. Wainwright Gas Co., [1932] 2 D. L.R. (Alta.) 145 (preferred against ordinary shareholders to dividends); In re New Zealand Hdwe. Co., [1926] N.Z. 76; In re Smeetons, Ltd. (In Liquidation), [1928] N.Z. 190.

${ }_{32}$ Cf. Morrisville Trust Co. v. Moon, 21 F.(2d) 716 (C. C. A. 3d, 1927). 
ration. Thus, an unpaid seller still in "possession" under an agreement of sale has sued for a declaration that he, rather than the defendant's receiver, has a prior claim to the goods. ${ }^{33}$ On the other hand, a secured creditor holding forest products assigned as security for money loaned to the now bankrupt debtor may sue the unpaid vendor for a declaration of the priority of his claim over the vendor's lien. ${ }^{34}$ Special depositors have by declaration claimed a right to a preferred status against a bank in receivership..$^{35}$ Other claims to priority, often involving difficult questions of ranking under contract or statute or equity, have been submitted and decided by declaration..$^{36}$

The advantage of these proceedings is that the issue of priority is segregated from the mass of issues likely to arise in receivership and that the administration of the estate may thus be facilitated and expedited. While it is true that the receiver himself can raise the issue of priority by a bill for instructions or an action for a declaration, he cannot be compelled to sue, a fact which should not bar creditors asserting preferences or priority from protecting their own interests.

Creditor or Receiver for Creditors Sues Debtor or Debtor's Assignee To Establish Validity of His Claim

A creditor is frequently faced with the necessity of establishing the existence of his claim against a debtor ${ }^{37}$ and by asserting it, of preventing the improper disposition or the dissipation of assets normally chargeable with the payment of his claim. This is often done by seeking a declaration against the debtor and his transferee that a deed or assignment of the debtor's property is void as in fraud of creditors ; 38 by as-

${ }^{33}$ Wrightson v. McArthur and Hutchisons, Ltd., [1921] 2 K. B. 807.

${ }^{3}$ Royal Bank of Canada v. Hodges, 41 B. C. 203, rev'd, 42 B. C. 44 (1929).

${ }_{35}$ Board of Trustees of East. St. Pen. v. Gordon, 16 D. \& C. 54 (Pa. 1931) (court declined jurisdiction on ground that remedy on the bond should first be exhausted).

${ }^{9}$ In re Lewis Merthyr Consol. Collieries, Lloyd's Bank v. The Company, [1929] 1 Ch. 498 (debenture holders $v$. workmen and others); Gowers v. Walker, [1930] 1 Ch. 262; In the Matter of the Estate of Gallagher, William Hogg \& Co. v. Gallagher, [1932] Ir. R. 35; Kedie's Trustees v. Stewart \& M'Donald, Ltd., [1926] Scot. S. C. 1019.

${ }_{37}$ Malone v. Romano, supra note 11 ; In re Hamilton \& Co., Hamilton \& Co. v. Overell \& Sampson Proprietary, [1924] N. Z. 386; RG. 27, 204, Nov. 5, 1890 (existence of plaintiff's claim against $A$ asserted against $B$, who owes $A$ money).

${ }^{39}$ Semenowich v. Melnyk, sutpra note 20 ; cross-bill to have deed declared mortgage for advances; Abbotsford Lumber, Mining \& Development Co.v. Stevenson, 35 B. C. 405 (1925); In re Schneideman Bros,, Ltd., Scott \& Martindale's Case and Kember's Case, No. 1, [1917] N.Z. 48 ( $S$ sold his business to company, taking shares issued to him as paid up. These he then sold to defendant. Creditors sue to establish that sale was a sham and that shares issued as paid up were really contributory.); RG. 33, 312, July 12, 1894 (assignee of a claim, pledged as security for the debt, sues other assignee of same claim to establish that his assignment is simulated and invalid, and that plaintiff has prior claim); RG. 35, 95, July 21 , 1895. Judgment creditor seeks declaration that transfer of debtor's property void plus order setting it aside: Union Bank of Canada v. Johnson, 3 Alta. L. R. 207 (1910); Cameron v. Mosely, supra note 15; Quinn v. M'Cool, sitpra note 24. 
serting against third persons or the debtor that the debtor has an interest in certain property, thus increasing his available assets ${ }^{30}$ by asserting that a sale of the debtor's property, though not invalid, is nevertheless subject to plaintiff's claim, such as an annuity. ${ }^{40}$

Receivers likewise have frequent occasion to seek declarations that certain property is the property of the bankrupt, ${ }^{41}$ that gifts or assignments by the bankrupt are void ${ }^{42}$ or constitute fraudulent preferences, ${ }^{43}$ or that alleged incumbrances in favor of third persons are invalid.44

\section{Plaintiff Alleges that Defendant Holds as Trustee for Him}

Situations frequently arise in which a plaintiff seeks a declaration that property or rights, held in the name of another, actually belong to the plaintiff. Plaintiff finds his security in a judicial determination that the defendant holds as trustee for the plaintiff-a decision which affords him adequate protection. ${ }^{45}$ Such a need arises in cases in which title to property was taken in the defendant's name, although the plaintiff furnished all, or part, of the purchase price. The motive is usually soine special confidential relation $;^{46}$ and the suit may be based upon some

${ }^{30}$ Whiteside and Aldridge, Assignees v. Merchants Nat'1 Bank, pending in Sup. Jd. Ct. Mass. (1933) (assignees for benefit of creditors sue trustees under a will and the debtor for declaration that the assignment included the debtor's interest in a trust estate created by his grandfather); Thomson v. Cushing, 30 Ont. R. 123 (1899); cf. Everts v. Kepler, supra note 11 .

${ }^{40}$ In re Profits \& Income Ins. Co., [1929] 1 Ch. 262; Parker v. Judkin, [1931] $1 \mathrm{Ch} .475$.

¿1 Gaffney v. Shepard, 108 Conn. 339, 143 Atl. 236 (1928) (that bankrupt has a vested interest in a trust fund created by his father's will); Official Assignee of Wylie v. Massey-Harris Co., 32 N.Z. 363 (1913); In re Haigh, [1922] N.Z. 750 (that chattels belonging to wife were assets of husband's estate); Official Assignee of McWilliam v. McWilliam, [1923] N.Z. 561; In re Haw, [1926] N.Z. 558; In re Richter, [1929] N.Z. 364 (that money paid into court as damages to bankrupt formed part of estate).

${ }^{2}$ Is re Menell et Cie., Regent Street Fur Co. v. Diamant, [1915] 1 Ch. 759 (that sums paid to defendants formed part of bankrupt's estate and must be turned back); In re Hume, In re Bell, Official Assignee of Reeves v. Paterson, all stipra note 15 .

${ }^{13}$ In re Drabble Bros., [1930] 2 Ch. 211 (that certain payments made by bankrupt just before bankruptcy and without knowledge of his condition are fraudulent preferences); In re Cochrane, [1925] N.Z. 15 (same, with knowledge); In re Rankin, 33 N. Z. 650 (1914); In re Hardy, No. 2, [1922] N.Z. 613; Official Assignee v. Tosswill, [1919] N.Z. 91; In re New Zealand Electrical Appliance \& Engineering Co., [1927] N.Z. 16.

"Campbell v. Official Assignee of Buckman, 28 N.Z. 875 (1909) (that bailment, if any, on certain engine, property of the bankrupt, was void, as not registered); In re Jensen, [1918] N. Z. 121; In re Buckingham, [1922] N. Z. 771.

${ }^{4}$ Sullivan v. Orpen, [1909] 1 Ir. R. 46 (court felt that no declaration of title was necessary, as the declaration that defendant held in trust for plaintiff would afford adequate protection).

${ }^{45}$ Business manager: Walker v. Silk, [1930] 4 D. L. R. (B. C.) 201 (wife's sister sought declaration that defendant husband was trustee of his wife's assets and should account because he had managed her estate during her life, paid family debts with her funds, and made investments in his own name with her funds); Davies $v$. Christakos, [1931] 1 D.L.R. (Manitoba) 1009, varying [1930] 2 D. L.R. 870 
improper claim to the whole, when the property was bought with mutual savings. ${ }^{47}$ The need for such a declaration is particularly pressing when for various reasons some third person has come upon the scene and is in a position to assert claims to the property.48 In many other instances the plaintiff may wish to assert his continued interest in property, although some factor has intervened which appeared to terminate his interest. The interest which he seeks to protect may be that of owner, cestui que trust, or creditor, but, in any event, it is vital for him to have a judicial determination that lapse of time, ${ }^{49}$ denial by defendant of the relation, 50 defendant's act-positive ${ }^{51}$ or negative ${ }^{52}-$ or the alleged termination of the agreement governing the relation ${ }^{53}$ has not had

plaintiff was an uneducated woman who had confided her funds to defendant for investment, defendant taking title in his own name). Family relations: Gascoigne v. Gascoigne, [1918] 1 K. B. 223; Keelan v. Garvey, [1925] 1 Ir. R. 1; Devoy v. Hanlon, [1929] Ir..R. 246; Galloway v. Galloway, [1929] Scotch S. C. 160; Challoner v. Challoner, [1930] 4 D.L.R. (Novia Scotia) 18. Miscellaneous: California Trust Co. v. Cohn, 7 P.(2d) 297 (Cal. 1932) (cross-complaint that plaintiff held property as trustee for itself and defendant); Waimiha Sawmilling Co. (In Liquidation) v. Waione Timber Co., [1923] N. Z. 1137 (defendants having acquired title by fraud or using title unduly to defeat plaintiffs rights).

"Such cases usually arise after family quarrels. Malone v. Romano, supra note 11 (agreement to buy farm, paying with joint earmings and savings, title to be taken in the name of the mother and stepfather); Official Assignee of McWilliam v. McWilliam, [1923] N.Z. 561; Roberts v. Brown, [1924] N.Z. 851 (here the trust declaration was an alternative prayer, a case in which a transfer to a third person was assailed for undue influence).

${ }^{4}$ In re Ioakimidis' Policy Trusts, Ioakimidis v. Hartcup, [1925] Ch. 403 (wife sued to establish her rights in proceeds of insurance policy on her husband's life, on which she had paid the premiums, defendant being husband's administrator); Blakey v. Trustees of Property of Pendlebury, [1931] $2 \mathrm{Ch} .255$ (plaintiff, who was assignee of original creditor and who had not given notice of the assignment, sought to establish his right to the security given by the bankrupt for advances) [but see South London Greyhound Racecourses Itd. v. Wake, [1931] $1 \mathrm{Ch}$. 496, in which the court denied the need for declaratory relief in a case in which the issuer of the security sought to establish that the defendant creditor had no-right to the benefit of a pledge agreement with the debtor stockholder]; Owens v. Greene, [1932] Ir. R. 225.

Keelan v. Garvey, supra note 46 (defendant had purchased the farm under statute and had finally secured title in her own name).

${ }^{\infty}$ Sullivan v. Orpen, supra note 45; Byrne v. Hughes, [1925] 1 Ir. R. 126 (that sum received by defendant for injuries to property was held in trust for plaintiff under lease covenant to repair); Rushbrooke v. O'Sullivan, [1926] Ir. R. 500 (that defendant insurance company, which had denied privity with plaintiff lessor, held fund payable to defendant after fire, as trustee for plaintiff for repairs under lease) ; Byron Hall, Itd. v. Hamilton, supra note 12; Styak v. Mountain [1922] N. Z. 131, aff'g [1921] N.Z. 137.

in Cameron v. Mosely, supra note 15 (creditor's interest in land sold with a view to defeating deficiency judgment secured after a foreclosure sale).

${ }_{53}$ In re Albert Road, Norwood (Nos. 56 and 58), [1916] 1 Ch. 289 (defendant corporation mortgagor's failure to convey to plaintiff mortgagee after foreclosure, defendant being about to dissolve); Byron Hall, Ltd. v. Hamilton, supra note 12 .

Malone v. Romano, supra note 47; Clayton v. Chambers, 32 N. Z. 65 (1912) (agreement to hold in trust oil and mineral concessions, alleged to have been terminated by withdrawal of one of the original settlers; question arising as to property to be sold to another firm). 
the effect upon his rights which the defendant claims, and that the defendant holds the legal title as trustee for the plaintiff.

\section{Plaintiff Clains the Right To Receive or Retain Benefits}

By virtue of statute, contract, will, or other instrument affecting legal relations, a plaintiff frequently has occasion to assert his right to receive or retain benefits, without demanding more coercive relief. This may be due to the fact that he is not too certain of his legal right and wishes to avoid the risks of attachment or of a drastic change of the status quo; or, more likely, to the fact that the declaration of rights adequately protects his challenged interests. For the most part, such an issue involves the future conduct of the parties, which, by construction of the relevant instrument conferring the disputed right or title, is thereby stabilized and made certain. In case of continuing relations, it is especially valuable because it enables the doubt or uncertainty giving rise to the issue to be removed and settled without disturbing the relationship, thus avoiding that rupture, often irretrievable, which other forms of procedure so often invite. And yet, notwithstanding these advantages of an action solely for a declaration, there is nothing to prevent a plaintiff from associating with his demand for a declaration of right to receive a benefit, a further prayer for an order or decree to deliver or perform in accordance with the court's declaration of rights.

In case of obligations performance of which covers a period of years, situations often arise in which one party to the contract, or his successor in interest, stands in need of a judicial determination, hinding upon all interested parties, that in the events which have happened the contract is still binding. By such declaration the plaintiff is put in a position to assert his rights without danger of being subjected subsequently to threat of ouster or other legal proceedings. His path is made smooth at the outset. Such issues arise in connection with contracts for the sale of land, ${ }^{54}$ long-term contracts for the supply of a com-

* Mayor, etc., of London v. Horner, sulpra note 19 (exercise of statutory power to purchase); In re Hawkins, Hawkins v. Dew \& Sons, [1926] Ch. 428 (widow of bankrupt seeks declaration whether death benefit goes to her or to creditors of husband's estate); In re Profits \& Income Ins. Co., stlpra note 40 (widow claimed rights as annuitant after bankruptcy of defendant company, and not as creditor); Byron Hall Ltd. v. Hamilton, supra note 12; West v. Dillicar, [1920] N. Z. 139; Hargreaves v. Dukes, [1931] N.Z. 1143. Like situations arise as to options to purchase: Abbott v. Union Trustee Co. of Australia, 41 C. L. R. 375 (1928); Williams v. Miramar, Ltđ., 32 N.Z. 97 (1911); Stannard v. Nicholas, [1920] N.Z. 78 . 
modity, ${ }^{55}$ or any other agreement involving a promise to do something over a long period of time or in the distant future. ${ }^{56}$

Without regard to the period allotted for performance, the issue of the continued validity of the relation and its attendant benefits may become important because of the acts of the parties. Faced with the possibility of default, the creditor may stand in need of a declaration which defines his interests in the collateral or property of his debtor. ${ }^{57}$ The question of possible dealings with the collateral may also be solved by the declaration, before there has been any breach to irritate the amicable relations of the persons involved. 58 So, the person named in -a will or designated by statute may in this fashion concisely assert his

${ }^{2}$ City of San Diego v. Cuyamaca Water Co., 209 Cal. 105, 287 Pac. 475 (1930) (priority of water rights); Orndoff v. Consumers' Fuel Co., $308 \mathrm{~Pa} .165,162$ At1. 431 (1932) (lessors of mineral rights under long-term leases sought a declaration as to the apportionment of royalties, in view of conflicting leases and assignments); Miscampbêll v. M'Alister, [1930] N. Ire. (Ch.) 74; Conigas Reduction Co. v. H. E. P. Commission of Ontario, [1931] 4 D.L.R. (Ont.) 391 (contract to supply electricity as perpetual, in view of the fact that defendant had refused to accept minimum fee while plaintiff's factory was shut down); Medalta Potteries, Ltd. v. City of Medicine Hat, [1931] 1 W.W.R. (Alta.) 217; Hamburg, Nov. 30, 1916, Soergel 1917,337 (duty to deliver at the end of the war).

to Ocean Coal Co. v. Powell Duffryn Steam Coal Co., [1932] 1 Ch. 654 (that plaintiff under true construction of corporate agreement was privileged to buy in only part and not whole of defendant's shares, as offered and refused) ; William Beardmore \& Co. v. Barry, [1928] Scot. S. C. (H. L.) 47, [1928] S. C. 101, [1927] S. C. 534 (continuance of obligation to secure purchasers, original obligor being defendant's testator) [cf. De Tchihatchef v. Salerni Coupling, Ltd., [1932] 1 Ch. 330]; Clarkson v. Canadian A. \& F. Ass'ce Co., [1931] 4 D. L. R. (Ont.) 769.

An interesting exemplification of the necessity for a determination of the existence of the legal relationship, before claims under it have accrued, arises out of the purported forfeiture and cancellation of a life insurance policy by the company, for alleged breach by the insured. The insured has a vital interest in having the policy declared alive and in force. Courts of equity have long recognized the necessity for such a judgment.

It is a little amusing to find a recent case in Missouri, in which the court renders the declaration sought, but, in view of the fact that Missouri does not yet authorize declaratory judgments, rejects the imputation that the judgment is purely declaratory. Missouri Cattle Loan Co. v. Great Southern Life Ins. Co., 52 S.W.(2d) 1 (Mo. 1932). Plaintiff, assignee of an insurance policy issued to $L$, sought equitable relief in the form of reinstatement of insurance contract and avoidance of alleged forfeiture of the policy. After the assignment, plaintiff had made the premium payments, which were required to be made at defendant's home office in Texas. Relying on defendant's assurance that it would give notice, and the fact that defendant had done so in the past, plaintiff did not make payments when no demand was made and then defendant declared the policy forfeited. Plaintiff tendered the amounts due when he discovered that payments had not been made. $L$ could no longer secure insurance, as his health had failed.

${ }_{57}$ Northern Banking Co. v. Carpenter, supra note 11 (equitable mortgage arising from the deposit of deed with plaintiff bank); National Bank v. M'Govern, supra note 11; Scott v. Scott, [1930] Scot. S. C. 903 (plaintiff divorcee claims right to share of defendant's trust estate, which defendant had sought to defeat by creating irrevocable personal trust); Carson v. Fraser, [1919] N.Z. 53; Nelson Dioceasan Trust Board v. Hamilton, [1926] N.Z. 342 .

${ }^{3}$ Brooklyn City R. Co. v. Kings County Trust Co., 214 App. Div. 506, 212 N. Y. Supp. 343 (2d Dept. 1925) (right under trust deed to release realty given as security on substitution of personalty of equal value); Burroughes v. Abbott, [1922] 1 Ch. 86. 
claim to an interest in an estate. ${ }^{59}$ The cestui que trust is served with equal efficiency when he desires to assert his rights to receive certain benefits under the terms of the trust. ${ }^{00}$ In all these instances the declaration protects the pecuniary interests of the property owner or creditor as soon as there is a definite indication of difficulty and dispute but before there has been any violation of a legal duty.

The identity of the person entitled to a fund of money accruing under a contract or other written instrument is also easily established by declaratory procedure. An outstanding example of the utility of this device is found in a dispute between the lessor and lessee or the mortgagor and mortgagee as to the use of insurance funds for repairs or restoration of the property which has been damaged. ${ }^{01}$ The declaration settles the issue before any of the money has been spent. The controversy may arise between the insured or some one claiming through him and the insurance company, in which case a declaration as to the right to the fruits of the policy is equally valuable. ${ }^{62}$ Other instances demonstrating the practical value of the declaration are those in which the plaintiff creditor wishes to assert his right to money which has become or will become due him, ${ }^{03}$ or in which after a death a beneficiary asserts

${ }^{\infty}$ In re Korvine's Trust, Levashoff v. Block, [1921] 1 Ch. 343 (right to certain funds mentioned in memorandum, as gift c. m.); In re Walton's Settlement, Walton v. Peirson, [1922] 2 Ch. 509 (widow sought declaration that deed avoiding settlement made settlement funds hers absolutely); In re Lejgh's Settled Estates (No. 2), [1927] 2 Ch. 13 (plaintiff sought to determine if she had the power of a life tenant after disentailing); In re Bund, Cruikshank v. Willis, [1929] $2 \mathrm{Ch}$. 456; Butler v. Butler, [1925] 1 Ir. R. 185 (beneficiary's executor sought declaration that gifts were charged on certain lands whose sale was pending); Graham v. Graham's Trustees, [1927] Scot. S. C. 388; Scott v. Scott, supra note 57; Oldenburg, Jan. 3, 1914, Soergel 1916, 499.

'o In re Cain's Settlement, Cain v. Cain, [1919] 2 Ch. 364 (widow sought declaration of her right to income without deduction for income tax); In re Duke of Westminster's Settled Est., Duke of Westminster v. Earl of Shaftesbury, [1920] 2 Ch. 445 (life tenant sought declaration fixing trustee's duty to improve according to his wishes without authorization of statute or court order); Drummond v. Bell-Irving, [1930] Scot. S. C. 704, aff'g [1929] S. C. 484 (plaintiff settlor of trust for second husband seeks declaration that she is privileged to withdraw and settle half of antenuptial trust settlement with first husband).

a Byrne v. Hughes, supra note 50; Rushbrooke v. O'Sullivan, supra note 50; Royal Ins. Co. v. Mylius, 38 C. L. R. 477 (1926).

${ }_{6}$ Anderson v. Equitable Life Ass. Soc., 42 T. L. R. 123 (K. B. 1925) (right to receive payments in gold marks); Honour v. Equitable Life Assurance Soc., [1900] 1 Ch. 852; Joyes v. National Ins. Co. of N.Z., [1932] N.Z. 802.

${ }^{e}$ Gerseta Corp. v. Gramatan Nat. Bank of Bronxville, 205 App. Div. 868, 198 N. Y. Supp. 385 (1st Dept. 1923) (issue of subrogation); Rosenblatt v. Surprise Bidg. Co., 223 App. Div. 426, 228 N. Y. Supp. 369 (1st Dept. 1928) (right to abatement of rent); Burnham v. Bennett, 141 Misc. 514, 252 N. Y. Supp. 788 (Sup. Ct. 1931) (right to money under award of public money); Villani v. National City Bank of New York, 143 Misc. 416, 256 N. Y. Supp. 602 (Sup. Ct. 1932) (depositor who had lost bank book sought declaration of right to funds; declaration demed). 
a claim by survivorship, ${ }^{64}$ or in which the plaintiff asserts a right to receive the benefits in a particular form. ${ }^{65}$

The source of the claim to benefits is not necessarily confined to contracts and other instruments in writing, for the demand may be based upon statutory provisions for pensions $s^{66}$ or other claims for money which it has become customary to grant by statute. ${ }^{67}$

In these cases the fact situation has been predicated upon the continued existence of a relationship and the purpose of the declaratory procedure has been its peaceful preservation. No less important are those cases in which the relationship is alleged to. have terminated and recourse is had to the courts so that the dissolution may be orderly, efficient, and observant of property rights. In cases of agreements to sell or lease, one of the parties to the contract may desire to secure a declaration that the contract drawn up between them is invalid ${ }^{08}$ or that it has been forfeited for reasons stated and that he is entitled to retain certain benefits which he had already received. ${ }^{69}$ Such declarations

"Owens v. Greene, supra note 48.

“ Anderson v. Equitable Life Ass. Soc., supra note 62; In re Société Intercommunale Belge d'Electricité, Feist v. The Company, 49 T.L. R. 8 (Ch. 1932) (right to be paid bond and coupons in gold and not legal tender sterling, in view of gold clause); Reichsgericht, March 30, 1931, 210/30 IV, Jur. Wochenschrift 60.2483; Reichsgericht, May 18, 1931, 7/31 IV, Jur. Wochenschrift 60.3263 .

${ }^{c}$ Right to receive pensions: Criswell v. Martin, 8 D. \& C. 425 (Pa. 1926) (judge-possible forfeiture after retirement through engaging in certain law practice); Birmingham v. Attorney-General, [1932] Ir. R. 510; RGZ. 86, 374 (1915); Karlsruhe, March 24, 1914, Soergel 1916, 501; cf. McCord v. Sproat, [1931] N. Ire. 119 , in which a claim for a pension was made under the rules of a union. Declarations as to method of fixing pension: Dewhurst v. Salford Guardians, [1925] Ch. 139 and 655 (inclusions of war bonuses); Hammond v. London County Council, [1931] 1 Ch. 540 (inclusion of time spent as substitute for soldier); Conway v. Minister for Defence, [1930] Ir. R. 633 (administrative dispute as to amount); Woods v. Dublin Corp., [1931] Ir. R. 396 (salary cut as improperly affecting pension rights).

"T Salary scales: Leyden v. Attorney-General of the Irish Free State, [1926] Ir. R. 334; Birmingham v. Attorney-General, [1932] Ir. R. 510; Smart v. Education Authority of the County of Perth, [1927] Scot. S. C. (H. L.) 22, rev'g [1926] S. C. 108. Statutory charges for improvements, etc.: West Ham Corp. v. Sharp, [1907] 1 K. B. 445; Auckland Gas Co. v. Auckland City Corp., [1922] N. Z. 1041; Auckland City Corp. v. Dawson, [1929] N. Z. 614; Nelson City Corp. v: Busbridge, [1930] N. Z. 269. Other statutory benefits: Board of Education of City of Detroit v. Campbell, 256 Mich. 350, 239 N. W. 370 (1931) (defendant as exempt from 1931 retirement statute); Greening v. Queen Anne's Bounty, [1932] 1 Ch. 348 (tithes); O'Connor v. Dwyer, [1932] Ir. R. 466 (poor relief); John G. Stein \& Co. v. Stirling County Council, [1928] Scot. S. C. (H. L.) 1, aff'g [1927] S. C. 659; Duke of Richmond v. Countess of Seafield, [1927] Scot. S. C. 833. 674.

${ }^{c 3}$ Harris v. McGregor, 32 N.Z. 15 (1912); Dickerson v. Otley, [1925] N.Z.

${ }^{\omega}$ Lease: Pickens v. Kizer, 11 Tenn. App. 551 (1930) (failure to work marble quarry); Mills v. McWilliams, 33 N.Z. 718 (1914) (that defendant's acts · constituted termination of contract, and plaintiff privileged to retain money held); Wingfield v. Rayne, [1916] N. Z. 157; Puhi Maihi v. McLeod, [1920] N. Z. 372; Ripeka Te Peehi v. Hutchison, [1921] N. Z. 758. Sale: Lock v. Bell, [1931] $1 \mathrm{Ch}$. 35 (failure to complete); Wilson v. Abbott, 7 Sask. 107 (1914) (failure to cultivate). 
settle the disputes and make it possible for the owners to deal with other persons without danger of assertion of a cloud through this incomplete or invalid contract. Such clearance of title by means of declaratory judgment has been expressly sanctioned by courts. ${ }^{70}$ The procedure is equally available in case of contracts not relating to land. ${ }^{71}$

The dissolution of a martiage by divorce or separation may evolie circumstances the practical solution of which lies in a declaration of the rights of the parties. Thus, the divorced wife may determine whether or not she has dower rights in her ex-husband's property, ${ }^{72}$ whether she may withdraw a portion of the funds settled under a marriage agreement for the purposes of another trust, ${ }^{73}$ or whether by the fact of the divorce she has become absolutely entitled to the benefit of the marriage settlement in view of its special terms. ${ }^{74}$

\section{Plaintiff Asserts Validity or Invalidity of His Ozen Act}

A plaintiff, in order to remain secure in his present position or to escape the dangers that an outside attack might invite, occasionally undertakes to protect himself by placing in issue the validity of his own past act. Usually, this consists in an effort to show that he is entitled to present relief, because the original act which bound him was void or voidable. Thus, a person who desired release from a marriage and sued for a declaration of its nullity, claimed, as a reason therefor, that his earlier divorce bad been improperly granted, because his domicil in the granting state had been "faked." 75 So, a promisor may seek to escape from an obligation before it has accrued, by suing for a declara-

${ }^{70}$ West Ham Corp. v. Sharp, supra note 67 . In deciding whether plaintiff administrative body was entitled to a declaration of a statutory lien on defendant's property for costs of improvements, Darling, $J$., remarked: " . . it does appear that it is a useful and convenient course to adopt, particularly with regard to the question of making good title if the plaintiffs should desire to sell the property. Therefore, although the order of the court is not absolutely a sine qua non, it is nevertheless one which the plaintiffs were entitled to obtain ... (at 447-8)."

${ }_{71}$ Johnson v. Sargant \& Sons, [1918] 1 K. B. 101 (return of money paid under contract terminated by war); Ocean Coal Co. v. Powell Duffryn Steam Coal Co., supra note 56 (agreement for purchase of corporate stock construed) ; AttorneyGeneral for Northern Ireland v. Forde, (Ch.) [1932] N. Ire. 1; Clydesdale Bank v. Walker \& Bain, supra note 29 ; Mills v. McWilliams, supra note 69.

${ }^{72}$ Scott v. Scott, supra note 57.

${ }^{73}$ In the Matter of Hogan, [1931] Ir. R. 257 (funds derived from sale of property held under a separation agreement as belonging to the guardian of the children); Drummond v. Bell-Irving, supra note 60 (new trust to be for the benefit of a second marriage).

"In re Meyrick's Settlement, Meyrick v. Meyrick, [1921] 1 Ch. 311.

"Hutchings v. Hutchings, [1930] 4 D.L.R. (Manitoba) 673. This is different from the action for jactitation of marriage in which the plaintiff, charged by the defendant with marriage, seeks a declaration that he is not married to the defendant. It also differs from the action of a spouse who asserts that the marriage still exists, because the other spouse's subsequent divorce was invalid. Baumann v. Baumann, 250 N. Y. 382,165 N.E. 819 (1929), aff'g 222 App. Div. 460, 226 N. Y. Supp. 576 (1st Dept. 1928). 
tion of its invalidity for illegality, uncertainty, or other alleged sufficient reason..$^{76}$ A company or public authority which issued or subscribed to an instrument creating liability may, in order to forestall a subsequent demand arising out of the instrument, seek a declaration that the instrument was void $a b$ initio, either on the ground of fraud ${ }^{77}$ or mistake, $^{78}$ or ultra vires. ${ }^{79}$ A vendor, in order to avoid the consequences of a bill of sale, may seek a declaration of its nullity, because of illegality, duress, misrepresentation, or other cause. ${ }^{80}$

On the other hand, a plaintiff affected by his own doubts or fears, and the doubts or fears of others, may, in order to insure his peace of mind and his vested rights, bring suit against a challenging defendant having an adverse interest, for a declaration of the validity of his past act. Thus, a bank which had purchased the assets of a solvent savings bank that had surrendered its cbarter, sued for a declaration of the validity of its challenged contract of purchase. ${ }^{81}$ A contractor who had concluded a street-paving contract with a city, sued defendants who had challenged the validity of the contract and the power of the city to make it, for a declaration of its validity, ${ }^{\text {s2 }}$ thus securing an adjudication on the disputed right before rather than after money had been expended in reliance upon its validity.

\footnotetext{
${ }^{7}$ Illustration (c) to $\$ 42$ of the Indian Specific Relief Act (1877), see Pollock and Mulla, Indian Contract and Speciric Retief Acts (6th ed. 1931) 840, provides: "A, covenants that, if he should at any time be entitled to property exceeding one lakh of rupees, he will settle it upon certain trusts. Before any such property accrues, or any persons entitled under the trusts are ascertained, he institutes a suit to obtain a declaration that the covenant is void for uncertainty. The Court may make the declaration."

"Auckland Provincial Fruitgrowers' Co-op. Soc., Itd. (In Liquidation) v. House, [1923] N.Z. 633 (company claimed declaration that its debenture to its own director, who had advanced money to the company when all parties knew it to be insolvent, was void as a fraudulent preference).

${ }^{8}$ Aetna Life Ins. Co. v. Richmond, 107 Conn. 117, 139 Atl. 702 (1927) (insurance company sought declaration that policy issued to $R$, with defendant $R$ as beneficiary, was void, because not issued while $R$ was in good health). In Life Ins. Co. of Australia v. Phillips, 36 C. L. R. 60 (1925), the insured claimed that the policy was void on account of mistake of fact.

${ }^{\circ}$ City of Milwaukee v. Chicago \& N.W.R. Co., 201 Wis. 512,230 N.W. 626 (1930) (that city's own ordinance obligating it to maintain certain structures was invalid) ; Broadview v. Saskatchewan Co-op. Creameries, Ltd., [1928] 1 D.L.R. (Sask.) 1119 (plaintiff town claims declaration that its contract to furnish current to defendant until 1934 at fixed rate was ultra vires); City of Swift Current v. Leslie, 9 Sask. 19 (1916); R. Jaffe, Ltd. (In Liquidation) v. Jaffe, [1932] N. Z. 168. ${ }_{80}$ Greene v. Riordan, supra note 20 ; Schnell v. Dent, 35 C. L. R. 494 (1925) (that plaintiff's bill of sale to defendant, given as security, was void); Broughton v. Waikari, 29 N.Z. 82 (1909). (deed void, and although unconfirmed and unregistered, it was a cloud on plaintiff's title); Roberts v. Brown, [1924] N.Z. 851; RG. Nov. 5, 1912, Soergel 1913, 449.

si Second National Bank of Nashua v. Old Guaranty Sav. Bank of Nashua, 84 N. H. 342, 150 Atl. 737 (1930).

\$ Morton v. Pacific Constr. Co., 36 Ariz. 97, 283 Pac. 281 (1929); Carolina Power and Light Co. v. Iseley, 167 S. E. 56 (N.C. 1933) (that plaintiff's contract with city to tear up street-car tracks and substitute motor busses was valid and did not, if executed, jeopardize franchise, as claimed by defendant taxpayers).
} 
Statutes occasionally authorize plaintiffs to establish by declaration the validity of a past act, when the facts warrant. ${ }^{83}$ A government official, having reason to fear an attack upon his past act and desiring to protect the status quo, has also on occasion sued for a declaration of the validity of his official act. ${ }^{34}$

\section{Incidence of Newly Imposed or Unanticipated Burdens}

It frequently happens that new burdens are imposed by statute or by an unexpected event which affects parties to a contract but leaves them in doubt as to who is to bear, or in what proportion, the new burden. Instead of one refusing to bear it and compelling the other to sue at law for a specific sum in contribution, which would involve or risk a breach of the contract, it has been found expedient, without breach, for one of them to sue the other for a declaration of the plaintiff's privilege not to pay or of the defendant's duty to pay. This requires a construction of the contract in the light of the new and unanticipated event and enables the parties to proceed with assurance as to their respective rights. As a substitute for refusal and open breach, it is a sensible method of litigating the disputed issue without disturbing the contractual status quo.

Thus, a lessee threatened or already charged with an increase of taxes or the imposition of a special assessment may sue his lessor for a declaration that the lessor and not the plaintiff lessee must bear the new burden. Were he flatly to refuse to pay, he might invite forfeiture of the lease, ejectment and damages for breach, a risk especially pregnant in long-term leases. ${ }^{85}$ The construction of the lease by declaration avoids such a hazard. The issue as to who bears a newly imposed lia-

${ }^{83}$ See McPhee v. Metlin, [1928] 2 D. L.R. (Nova Scotia) 989 (application to declare as good service the personal service of a writ on an infant, under Judicature Act, 1920, 9, r. 4).

st The King v. Paulson, 15 Can. Ex. 252 (1914) (information for a declaration that certain coal mining leases had been validly cancelled and, if not so, in alternative, declaration that a subsequent lease had been improvidently issued and should be cancelled); cf. Fidelity Nat. Bank \& Trust Co. v. Swope, supra note 3 (city sued to establish validity of bonds issued for public improvements).

${ }^{85}$ Lessee v. lessor: Transport Oil Co. v. Bush, 114 Cal. App. 152, 1 Pac. (2d) 1060 (1931) ; McCrory Stores Corp. v. S. M. Braunstein, Inc, 102 N. J. L. 590 134 Atl. 752 (1926) (whether lessee or lessor had to bear tax increase laid before, but falling due after, October, 1920) ; Bodega Co. v. Read, [1914] 2 Ch. 283, 757; In re Salter and Awdry's Lease, Property \& Estates Co. v. Blunt, [1921] $2 \mathrm{Ch}$. 141 ; Banner Coal Co. v. Gervais (No. 1), 18 Atla. I. R. 535 (1922). Lessor v. lessee: New Haven Ice Co. v. Hygienic Ice Co., Case 26361, New Haven (1927) Thornbury v. Forbes, 7 D. \& C. 184 ( $\mathrm{Pa} .1925$ ) (surface-owner v. lessee of oil rights, that tax is divisible between them); Henderson v. Gurr, 32 N. Z. 785 (1913). 
bility, incurred or contested, may also involve other contracts, e.g., for services $^{86}$ or supplies ${ }^{87}$ or sale or mortgage. ${ }^{88}$

The conflict as to the incidence of a burden or liability may further arise not between parties to a contract, but between persons in noncontractual or statutory relations, ${ }^{89}$ including litigating public bodies. ${ }^{90}$ In many of these cases an issue of law was thus determined before one or the other party, by precipitate action, had risked the commission of a legal wrong and exposed himself to irretrievable loss. In others, where an expenditure had already been incurred but it was desired that defendant share or bear it, the declaratory action was merely a milder substitute for the more provocative executory action. When directed

${ }^{8 s}$ Employer v. employee: S. J. \& E. Fellos, Itd. v. Corker, [1918] 1 Ch. 9 (employer sues for declaration whether excess profits duty deductible from profits in determining defendant's salary); Patent Castings Syndicate v. Etherington, [1919] $1 \mathrm{Ch}$. 306, [1919] 2 Ch. 254. Employee v. employer: Commonwealth ex rel. Schnader, Att'y-Gen'1, v. Nelson-Pedley Constr. Co., 303 Pa. 174, 154 At1. 383 (1931) (when building built by defendant contractor for plaintiff state was $80 \%$ completed, it burned, whereupon plaintiff sues for declaration that defendant must bear loss and rebuild) [cf. also Commonwealth ex rel. Schnader, Att'y-Gen'] v. Evans, $304 \mathrm{~Pa} .445,156$ Atl. 139 (1931), and cases following in 304 Pa.]; Meek v. Port of Iondon Authority, [1918] 1 Ch. 415, [1918] 2 Ch. 96 (that defendant employer under duty to pay income tax on plaintiff's salary); RG. III, Dec. 12, 1911, Soergel 1912, 492 (that defendant is under duty to hold plaintiff harmless from claims of third person for building costs) ; RG. VII, Jan. 28, 1913, Soergel 1913, 498 (owner sues builder for declaration that latter is liable for damages to neighbor, claimed against plaintiff).

${ }_{87}$ New Haven Water Co. v. City of New Haven, 106 Conn. 562, 139 At1. 99 (1927) (that defendant city, not plaintiff, is bound to pay federal income tax, not contemplated when contract was made); Johnson v. Mortenson, 110 Conn. 221, 147 Atl. 705 (1929) (contractor sues subcontractor for declaration as to who is liable for workmen's compensation due a laborer's widow, and whether either can recover from the other sums paid or to be paid in future).

ss In re Farrer \& Gilbert's Contract, [1914] $1 \mathrm{Ch}$. 125 (vendee v. vendor, that former is free from rent-charge, of which neither party had knowledge when contract made); In re Woking Urban Dist. Council (Basing-Stoke Canal) Act, 1911, [1914] 1 Ch. 300 (Canal Co. v. mortgagee for construction of statute for arbitration as to division of financial burdens); Terroni and Necchi v. Corsim, [1931] 1 Ch. 515; Dahm v. Stinn, 21 Alta. L. R. 88 (1925); Kelsey v. Tingey, [1922] N.Z. 313 (who to bear costs of improvements ordered by city).

so Winton Borough's Petition, 16 Del. Co. R. 539, 25 Lack. Jur. 173 (Pa. 1924) (apportionment of costs of paving) ; Cromin v. Dougherty, $100 \mathrm{~Pa}$. Super. Ct. 463 (1931) (plaintiff, owner of party-wall torn down by defendant but which city ordered rebuilt, sues for declaration that defendant is under duty to share costs); I $i r$ re England's Settlement Trusts, Dobb v. England, [1918] $1 \mathrm{Ch}$. 24; Town of Lunenburg v. Municipality of Lunenburg, [1932] 1 D. L. R. (Nova Scotia) 386; Mitchell v. Hayes, [1926] N.Z. 262; RG. IV, Feb. 25, 1909, Recht 13, No. 1342, JW. 1909, 223.

${ }^{10}$ Bruce County v. Lakes Drainage Dist., [1918] N.Z. 807 (plaintiff county, having erected canal by public loan, proposed, after a flood, to build new canal instead of repairing old one, and seeks declaration that costs should be borne by defendant drainage district and not by plaintiff county); RG. VI, Mar. 11, 1918, Recht 18, No. 1026, Soergel 1918, 231 (plaintiff health insurance fund sues police for declaration that latter must repay to plaintiff cost of hospitalization ordered by police); Bavaria, OLG. Nov. 21/Dec. 4, 1911, Das Recht 1912, No. 623, Soergel $1912,495$. 
to public bodies, the effect of such proceedings is practically identical with that of an executory action.

\section{Defendant's Duty To Act}

Those who have rights under contract or statute are frequently faced with a threat or risk of breach or violation by the defendant. Their fear of loss and prejudice persuades them to seek to avoid a breach by suing for a declaration of their rights. Such a declaration serves as a warning to the defendant and reassures the plaintiff in the enjoyment of his rights. It removes the cloud generated by the threat or danger of improper action by the defendant, confirms the plaintiff's rights, and stabilizes a doubtful or uncertain or challenged legal relation. It thus serves a most important social function in settling disputed rights at the inception of the controversy, saves from destruction and violence an existing status quo, preserves contracts against threatened breach, holds parties to their contractual and statutory duties, and avoids the economic and social damage which breach would entail. It acts as a preventive and conservatory measure, saving existing relationships from the risks of breach, violation, injury, and destruction. Issue is joined while the relationship still subsists and before irretrievable losses have occurred by reason of one or the other party acting upon his own interpretation of his rights.

A defendant who denies the existence of the contract or of an obligation under it may thus be held to his promise by a declaration that the contract or the disputed duty still subsists. ${ }^{01}$ This may be of vital importance, not only to insure the plaintiff in the enjoyment of the disputed right, but to enable him to convey title thereto. ${ }^{.2}$

${ }^{\text {D1 }}$ McClintock v. Frame, 98 Cal. App. 338, 276 Pac. 1033 (1929) (that defendant, wife of purchaser, was bound by agreement to assume the mortgage debt, notwithstanding her failure to sign a second amending agreement); Missouri Cattle Loan Co. v. Great Southern Life Ins. Co., supra note 56 (that a policy which defendant sought to void for failure to pay premiums is still in force-brought as action in equity to declare forfeiture invalid and policy reinstated. Although court says the judgment is not "merely declaratory," it is in fact nothing else); City of Bayonne v. East Jersey Water Co., 108 Atl. 121 (N. J. Eq. 1919) (that plaintiff has rights under assignment to receive water from defendant, against defendant's claim that contract unassignable); Alumnae Ass'n of the William Penn High School for Girls v. Trustees of the Univ. of Penna., 15 D. \& C. 769 (1931), aff'd, $306 \mathrm{~Pa} .283,159$ Atl. 449 (1932) (plaintiff seeks declaration that trust gift is still in force, after defendant seeks release from it); Medalta Potteries, Ltd. v. City of Medicine Hat, supra note 55; Hargreaves v. Dukes, supra note 54 (that agreement to sell farm to plaintiff was still in force, notwithstanding plaintiff's failure to perform condition, and that defendant disabled from cancelling and taking possession); Iandesarbeitsgericht Kiel, Oct. 3, 1928, Bensheimer IV, 84; RG. 12, 146, Dec. 20, 1882; RG. Oct. 5, 1912, Soergel 1913, 500.

' Never-Stop Railway (Wembley) v. British Empire Exh., [1926] Ch. 877 (plaintiff, having right to build railway on defendant's land, with benefit of renewal option, claimed privilege of selling it, against defendant's claim of termination of contract for alleged failure to use option to renew). 
Where the validity of an agreement, as a reason for refusing performance, is challenged by a defendant, the plaintiff may seek a settlement of the point in dispute by suing for a declaration of the validity of the agreement instead of for performance. ${ }^{93}$ So, when a fire insurance company sought to escape from the obligations of a policy on which the plaintiff had paid a premium to an absconding agent, by repudiating the authority of the agent because he had secured no license, the California Supreme Court sustained the propriety of an action by the insured declaring the validity of the contract and that the company was bound.94 Again, where land had been sold to the plaintiff by a co-tenant of the defendant, who, after apparently giving his consent to the terms of the contract for a consideration, later claimed that he was not bound thereby and claimed the land both against the seller and the plaintiff, a declaration was issued-although the action was for specific performance-that the agreement between the seller and the plaintiff was binding on the defendant.95

Actions have thus been brought against covenantors, seeking a declaration of a duty to keep premises in repair ${ }^{96}$ or to furnish lateral support.97 Where breach of the covenant has already occurred, the action may combine a prayer for a declaration of the continuing duty, with a prayer for damages for the past breach and injunction against an immediately threatened further breach. Actions have been brought against administrative authorities or public service corporations for declarations of their duty to keep roads in repair or perform other continuous services. ${ }^{98}$

\footnotetext{
${ }^{63}$ Huntoon Co. v. Kolynos, Inc., [1930] 1 Ch. 528 (That defendants were violating a patent license by violating condition; answer, denial of violation and condition illegal. Dismissed, because validity of patent involved); Reichsarbeitsgericht, Sept. 19, 1928, Bensheimer IV, 80 (labor union v. hotel, member of association party to collective wage agreement, that defendant could not validily pay auxiliary chambermaids out of the "trunc", service-fund charged to guests); RG. 109, 351, Dec. 17, 1924 (that agreement for sale of property was valid, notwithstanding false documentation).

${ }^{o s}$ Frasch v. London \& Lancashire Fire Ins. Co., 213 Cal. 219, 225, 2 P.(2d) 147 (1931): "The fact that the policy may subsequently be found to contain a clause authorizing its cancellation by the defendant company upon five days' written notice to the assured, need not destroy plaintiff's right to an adjudication of the question here involved, for should it be found that plaintiff had properly made payment to Booth as agent for the defendant company then, in the event of such suggested cancellation, he would unquestionably be entitled to a pro rata return of the premium." Cf. also Western Australian Ins. Co. v. Dayton, 35 C. L.R. 355 (1924) (that policy was binding, notwithstanding untrue answers of insured filled in by insurance agent); RG. 121, 154, May 16, 1928.

${ }_{05}$ Waimiha Sawmilling Co. (In Liquidation) v. Waione Timber Co., [1922] N. Z. 892 (that plaintiff's contract with $H$ was binding on defendant); West $v$. Dillicar, [1920] N. Z. 139.

${ }^{\infty}$ In re Field, Sanderson v. Young, [1925] Ch. 636; Horlick v. Scully, [1927] 2 Ch. 150.

or Sack v. Jones, [1925] Ch. 235.

is Hertfordshire County Council v. Great Eastern Ry. Co., [1909] 1 K. B. 368, [1909] 2 K. B. 403 (duty to maintain section arising from alteration of -level);
} 
Plaintiffs asserting rights under long-term contracts may claim, in the event of breach or threatened breach, that the contract has a certain period still to run and that defendant is under a duty to perform without interruption. Thus, a city claiming the right to receive water under a contract assigned to it sued the defendant, who refused further delivery on the ground of non-assignability of the contract, for a declaration of continuing duty to deliver. ${ }^{99}$ Private lessors of oil leases may claim continuing royalties, which defendant lessee has undertaken to terminate under its interpretation of the contract. ${ }^{100}$ Again, it is not uncommon, where breach is threatened, to claim a declaration that the contract has a definite term still to run and that the defendant's duty is continuous throughout. ${ }^{101}$ The difficulties of a mandatory injunction to perform a personal contract encountered in Lumley $v$. Gye can for the most part be overcome by a declaration that the defendant has a duty to perform exclusively for the plaintiff and not to enter the employ of the defendant.103

Security in the main looks to the future. Two important types of interest in the establishment of rights in the future are competently protected by declaration. The first is exemplified by cases in which the

Att'y-Gen'l v. Sharpness New Docks, [1914] 3 K. B. 1, rev'g [1913] 1 K. B. 422 (measure of defendant's duty to repair); In re Working Urban Dist. Council (Basing-Stoke Canal) Act, 1911, supra note 88; Thompson v. Wakapuaka Drainage Board, [1929] N. Z. 548.

Declaration is also used to ascertain the apportionment of statutory duties. Township of Kenyon v. Township of Charlottenburgh, 53 Ont. L. R. 22 (1922) (declaration that certain highways, being part of boundary between the parties, must be maintained by both) ; Chairman, etc., of Eltham County v. Chairman, etc., of Waimate West County, 29 N.Z. $309^{\prime}$ (1909); Bruce County v. Lakes Drainage Dist., [1918] N.Z. 807.

${ }^{\circ}$ City of Bayonne v. East Jersey Water Co., supra note 91 (plus injunction and specific performance); cf. also McIntyre v. Consolidated Water Co., 205 Cal. 231, 270 Pac. 444 (1928) (action for declaration of defendant's duty to supply water at agreed rates, notwithstanding defendant's conveyance of property to city, which revoked contract and refused supply except at higher rates); Corporation of Dist. of Maple Ridge v. Western Power Co. of Canada, 37 B. C. 252 (1926) (duty to supply power, defendant fearing to perform because by-law failed to pass).

${ }_{100}$ First National Bank of Redondo v. Standard Oil Co. (Cal.), 91 Cal. App. 705,267 Pac. 548 (1928) (under an oil lease defendant had the right to stop drilling after the completion of the first well and terminate, except as to ten acres surrounding the producing well; defendant exercised this right and notified plaintiff depositary for the lessors under a pooling scheme); Duguid v. Muirhead, [1926] Scot. S. C. 1078 (that defendant lessee was under duty to quit without further notice); Cole v. Wellington Dairy Farmers' Co-op. Ass'n, [1917] N.Z. 372; RG. 66,422 , Nov. 4, 1907 (duty to deliver milk to plaintiff exclusively until 1910, and disability to deliver to other dairies for six years); RG. VII, June 12, 1923, Soergel $1923,154$.

${ }_{101}$ Crediton Gas Co. v. Crediton Urban Dist. Council, [1928] Ch. 174 (that defendant's notice of termination of plaintiff's service contract, having no date of termination, was inoperative); Haldane v. Haldane, [1921] N. Z. 612; RG. 113, 410, May 11, 1926; Kiel, OLR. Nov. 10, 1909, Soergel 1910, 508 (that contract will terminate at given date in future).

${ }_{102} 2$ E. \& B. $216(1853)$.

${ }^{103}$ Rely-A-Bell Burglar and Fire Alarm Co. v. Eisler, [1926] Ch. 609. 
plaintiff is enabled to sue for a declaration of his right in principle, although a specification of his damages is not yet possible. This may be because if he did not sue now, the statute of limitations might run against him ${ }^{104}$ or because he might in other ways be prejudiced by delay. ${ }^{105}$

The second is exemplified by claims of vested rights to future advantages. Their present establishment removes clouds from titles, clarifies disputed rights, and enables the parties to know what they may expect and to govern themselves accordingly. One of the most interesting of such cases was Post v. Metropolitan Casualty Ins. Co. of New York. ${ }^{106}$ Here the defendant insurance company had insured a railroad against losses in excess of $\$ 25,000^{\circ}$ on account of accidents. The railroad was insolvent. Mortgages were being foreclosed, so that nothing would be left for unsecured creditors. Plaintiff had causes of action based on accidents, combined judgment on which would exceed $\$ 25,000$. On account of the railroad's financial condition, plaintiff sought to determine by declaratory judgment whether defendant was under a duty to pay future judgments against the railroad in excess of $\$ 25,000$.

Those who are obliged to pay damages in tort, or otherwise, occasionally implead or sue insurance companies, sureties, or third persons for a declaration that the impleaded defendant is under a duty to reimburse or to bear the loss. ${ }^{107}$

An official may by declaration claim his vested right in a pension payable on retirement in the future. ${ }^{108}$ In one case a girl was held to have a legal interest in a declaration of the defendant's contractual duty

${ }^{204}$ Supra, p. 652 et seq.

${ }^{105}$ Soergel, Jahrbuch des Verwaltungsrechts V, 473 (1911) (plaintiff, fearing a repetition of litigation later, may sue for a declaration on the merits, if it will decide the whole issue and prevent later dispute [especially if later decision would be ineffective]) ; Hamburg, Oberverwaltungsgericht II, No. 15, in Lassar, Reichsverwaltungsgericht, 34 (private school owner sues to establish right not to cut classes in future); $c f$. Pierce v. Society of Sisters, 268 U. S. 510,45 Sup. Ct. 571 (1925).

254 N. Y. 541, 173 N.E. 857 (1930), aff'g 227 App. Div. 156, 237 N. Y. Supp. 64 (4th Dept. 1929).

${ }_{107}$ Malley v. American Indemnity Co., 297 Pa. 216, 146 Atl. 571 (1929) (Policy holder sought declaration of defendant insurer's duty to pay, after defendant had defended a case brought against plaintiff on the policy, failed to prosecute an appeal, and then repudiated liability under the policy. The court remarked that there were several other remedies open to plaintiff and that "the presence of these direct remedies would not affect the right to a declaratory judgment, for reasons unnecessary to state" (at 573); Dependable Upholstery, Ltd. v. Brasted, [1932] 1 K. B. 291 (suit by one sublessee against another for difference in reduced statutory taxes and contract; defendant seeks to pass on liability, if any, to original lessor) ; RG. 61, 164, June 29, 1905 (action by co-operative society against state for declaration that state must reimburse society for insurance it may have to pay its members because of accident on state railway) ; $c f$. City of Corbin v. Underwood, $221 \mathrm{Ky} .413,298 \mathrm{~S}$. W. 1090 (1927) (city under a duty to reimburse jailer for expenses incurred in producing prisoners in court).

${ }^{203}$ RG. 59, 162, Nov. 15, 1904. 
to pay her a given sum upon her marriage, ${ }^{100}$ whereas in the case of a statutory duty of a father to give his daughter a dowry, at least her engagement to be married was deemed necessary to give her a legal interest in the declaration. ${ }^{110}$ The German Supreme Court recently sustained an action by the widow and daughters of a man killed in an automobile accident, for a fixed annuity and a declaration that if the liability were increased by legislation, they should receive the benefits thereof. The court maintained that there was no objection to a declaration of conditional liability. ${ }^{111}$

Those interested in long-term leases may by means of declaration solve difficulties which lie in the path of continued peaceful relations. Thus, the duty of the lessee to accept a renewal before the rent is fixed, ${ }^{112}$ or the duty to take the notice to quit as valid, ${ }^{113}$ or the duty to accept a certain type of building after a fire, ${ }^{114}$ may be determined by declaration.

In cases of contracts for the sale of land, the buyer finds the solution of his problem in the declaratory judgment procedure, for by it he can establish the seller's duty to abide by the contract ${ }^{115}$ or to pay over certain fruits of the property. ${ }^{116}$

As a result of a relationship arising from business dealings or the ownership of property, it may become vital to ascertain the duty to do one specific act which influences the whole course of the subsequent intercourse. Thus, a landowner may seek a declaration of his neighbor's duty to build a party wall, ${ }^{117}$ or the person entitled to money may fix by declaration the duty to apply funds in a given fashion. ${ }^{118}$

\footnotetext{
${ }^{103}$ RG. 35, 392, April 18, 1895.

${ }^{100}$ RG. 49, 370, June 17, 1901.

1 RG. 127, 179, Jan. 27, 1930.

112 Gisborne Harbor Bd. v. Barker, 29 N. Z. 801 (1909).
}

${ }^{113}$ Croft v. William F. Blay, Ltd., [1919] $1 \mathrm{Ch}$. 277 , [1919] $2 \mathrm{Ch} .343$ (lessor sued as to date of tenancy, after lessee had held over and paid the next quarter's rent); In re Bebington's Tenancy, Bebington v. Wildman, [1921] 1 Ch. 559; In rc Knight \& Hubbard's Underlease; Hubbard v. Highton, [1923] 1 Ch. 130.

${ }^{144}$ Girard Trust Co. v. Tremblay Motor Co., 291 Pa. 507, 140 Ati. 506 (1928) (statute, subsequent to lease, prohibited erection of buildings like that dcstroyed; lessee defendant claimed abatement of rent if smaller building was erected); Sclinee v. Elston, 299 Pa. 100, 149 Atl. 108 (1930) (plaintiff lessee; lease with option to purchase carried provision that lessee should maintain insurance for benefit of lessor ; issue: crediting of insurance money, paid over after fire, when lessee exercised option before beginning to rebuild).

${ }^{115}$ In re Des Reaux \& Setchfield's Contract, [1926] Ch. 178 (seller had made no effort to meet requisition on title and then attempted to rescind); Toohey v. Gunther, 41 C.I.R. 181 (1928) (here the plaintiff buyer sought to establish seller's no-right to rescind and his own right to do so).

${ }_{116}$ In re Lyne-Stephens \& Scott-Miller's Contract, [1920] 1 Ch. 472 (money payable after date of contract as compensation for breach of covenant by lessec).

${ }_{117}$ Cronin v. Dougherty, supra note 89.

${ }^{115}$ Evling v. Israel \& Oppenheimer, Ltd., [1918] 1 Ch. 101 (shareholder sued to fix duty to apply profits to dividends) (In re Duke of Westminster's Settled Estates, Duke of Westminster v. Earl of Shaftesbury, [1920] $2 \mathrm{Ch} .445$; Jacobs v. Batavia \& General Plantations Trust, [1924] 1 Ch. 287, [1924] 2 Ch. 329; Agricultural Wholesale Soc. v. Biddulph and District Agricultural Soc., [1925] Ch. 769. 
A declaration may be sought of the government's duty to act in a particular instance, where failure to act as requested will jeopardize the future rights of the plaintiff. ${ }^{119}$

\section{Defendant's No-right or Disability}

The status quo may be preserved against impairment by seeking to prevent the defendant from violating a contract or the law. The plaintiff thus asserts the defendant's no-right or disability to act to the plaintiff's injury. This type of security has usually been achieved by a bill of injunction, and while in these cases the prayer for a declaration is often combined with a request for injunction or other relief, an injunction is not always obtainable, whereas the declaration will usually serve as an adequate measure of preventive relief. The continuance of the act complained of is as a rule interrupted by a declaration of its illegality or invalidity, and that suffices.

This is the common form by which stockholders and members of organizations seek to prevent improper and ultra vires acts by their companies or societies infringing the corporate articles or by-laws and to preserve them against impairment, present and future. Where the danger of harm is imminent, a request for an injunction is often added. ${ }^{120}$ If the challenge is addressed to corporate resolutions, the prompt declaration of their invalidity is likely to prevent their execution and a consequent injury.

In order to prevent long-continued violations of contract or law, it is often expedient to challenge the defendant's acts at their earliest manifestation by suing for a declaration of invalidity or illegality - that is, of defendant's no-right or disability to violate as planned or begun. ${ }^{121}$

${ }^{119}$ London County Council v. Port of London Authority, [1914] 2 Ch. 362 (duty to approve plaintiff's sewer works); Hardley v. Mt. Roskill Road Board, [1923] N.Z. 897 (duty to approve plaintiff's plan for subdivision); James v. Waimairi County Council, [1929] N.Z. 449 (duty to permit plaintiff to erect a shop on his land or give compensation).

${ }_{120}$ In each of the following cases the declarations were implemented by injunctions: Dafen Tinplate Co. v. Llanelly Steel Co., [1920] 2 Ch. 124 (plaintiff shareholder sought declaration that resolution purporting to alter an article regulating compulsory transfer was invalid); Evans v. Brunner, Mond \& Co., [1921] 1 Ch. 359 (plaintiff stockholder sought a declaration that a resolution proposing a distribution of money to encourage scientific research was ultra vires); Jenkin v. Pharmaceutical Society of Great Britain, [1921] 1 Ch. 392 (plaintiff member of defendant society sought declaration that certain of its operations were beyond-its corporate powers); Wise v. Lansdell, [1921] 1 Ch. 420; Dibble v. Wilts \& Somerset Farmers, Ltd., [1923] 1 Ch. 342; Steinberg v. Scala (Leeds), Ltd., [1923] 2 Ch. 452; National Sailors' \& Firemen's Union of Great Britain and Ireland v. Reed, [1926] Ch. 536; Cotter v. National Union of Seamen, [1929] 2 Ch. 58.

No injunction was apparently asked in Piercy v. S. Mills \& Co., [1920] $1 \mathrm{Ch}$. 77 (plaintiff manager of defendant company sought a declaration that the allotment of shares by the directors to secure voting power was void).

${ }_{123}$ This is the common way to assert the non-existence of an easement or other right in land claimed by the defendant. Illustration (a) to Indian Specific Relief Act, $\$ 42$, and supra, p. 654 .

Owens v. Owens' Ex'r, $236 \mathrm{Ky} .118,32$ S.W.(2d) 731 (1930) (executor 
The government itself may bring an issue to early determination by claiming a declaration that the defendant by his acts is violating the law, from which determination consequences necessarily flow. ${ }^{122}$

\section{Defendant's Liability}

In a number of the situations in which the plaintiff seeks relief from peril or insecurity, it has been observed that the plaintiff has merely initiated proceedings which the defendant himself might have begun. The issue and the contested claim of right existing, it is immaterial, as the Supreme Court has said, ${ }^{123}$ which of the parties commences the suit. Thus, a government claiming taxes to be due under certain circumstances may, instead of awaiting a suit for injunction or immunity or risking an erroneous levy, itself move for a declaration that the taxes are due as claimed or that the asserted immunity does not exist. $^{124}$

\section{Defendant's Power To Act}

A plaintiff may establish his own security by seeking a determination of the defendant's powers, the exercise of which affects him. The need for such a declaration may lie in the plaintiff's desire to relieve

sought a declaration as to the devisee's power of sale under a gift to $A$ for life and, on $A$ 's death or reinvestment after sale of the land, to $A$ 's children; devisee claimed power to sell); Collette v. Lochic, Pemberton \& Co., 63 Sol. J. 24 (Ch. 1918) (plaintiff employee sought a declaration that defendant had no right to make deductions from his salary for taxes, because plaintiff was not a "manager" within statutory terms); Hanbury v. Bateman, [1920] 1 Ch. 313 (person holding the burdened land sought to determine whether a power to charge had bcen validly exercised ; $H$ was given power to charge the land if $W$ came into possession of certain other property and exercised this power three years before $W$ came into possession) ; Torbay Hotel v. Jenkins, [1927] 2 Ch. 225; Choma v. Chmelyk, 13 Alta. L. R. 298 (1918); Wanek v. Thols, [1928] 1 D. L.R. (Alta.) 873 (plaintiff sought declaration that defendant had no-right to breach covenant to refrain from entering into competition with plaintiff; breach alleged through sale of business); RG. 41, 369 (1898); RG. May 23, 1908, Soergel 1908, 491; Reichsarbeitsgericht, Sept. 19, 1928, Bensheimer IV, 80; Reichsarbeitsgericht, Sept. 25, 1929, Bensheimer VII, 162 (declaration that employer had no-right to discharge plaintiff and that the contract continued).

${ }^{123}$ Att'y-Gen'l v. Denby, [1925] Ch. 596 (that defendant's building in the process of erection violated statutes; plaintiff also asked injunction and mandatory order).

${ }_{123}$ Fidelity Nat. Bank \& Trust Co. v. Swope, supra note 3.

${ }^{124}$ Magistrates of Hamilton v. Bent Colliery Co., [1929] Scot. S. C. 686 (plaintiff administrative authority claimed declarator that defendant was an occupier of minerals in a certain district within the terms of a certain statute and that plaintiff could impose tax; dispute arose because map defining boundaries of defendant's property had been lost); Mayor, etc., of Miramar v. Devoy, 34 N. Z. 1072 (1915); Northcote Borough Council v. Buchanan, [1930] N. Z. 798. In Viola School Dist. v. Canada Sask. Land Co., 3 Sask. 498 (1910), the court ruled, in an action for a declaration of defendant's liability to the plaintiff's taxing power, that until an assessment had been made there was no "cause of action." This is very questionable. The:issue was whether defendant was within plaintiff's taxing jurisdiction, and this was justiciable before an assessment had been made. There must, of cotrse, have been a claim of right to assess. 
himself from doubt and uncertainty and to clear his right, usually a right in property. The defendants may be public authorities or private persons, but the effect of the declaration is to remove a cloud from the plaintiff's rights.

Thus, a grantor who had subdivided his land and covenanted with his first grantee that detached residences would be built upon it, contracted to sell a lot to a vendee who desired to erect a duplex building. The first grantee having threatened to enjoin such erection and the vendee fearing to complete the purchase, the grantor brought an action against the vendee and the first grantee for a declaration that under the terms of the restrictive covenant, the defendant vendee was privileged to erect the desired duplex. ${ }^{125}$

Again, an English college, desiring by redemption to clear its property of certain perpetual rent charges, sued the public authorities ostensibly entitled to such charges but doubtful of their statutory authority to accept absolutely and dispose of the payment offered, for a declaration that the defendants were empowered so to accept and dispose. The question turned upon the construction of the statute. The defendants, though willing to accept, doubted their powers and alleged in defense the difficulties involved in the plaintiff's view of the defendants' powers. The court's decision removed the uncertainty. ${ }^{126}$

The doubts of defendant trustees, questioning their own powers to act, are thus on occasion removed by an action instituted by those who anticipate advantage from the clarification of the legal position, whether it be public authority or private beneficiary. ${ }^{127}$

\section{Security of Status}

Frequently the simplest way to insure the continued enjoyment of rights or prevent their loss or deprivation is to place in issue the single legal fact, character, or classification upon which the rights depend. This often involves merely a question of the plaintiff's status. If he can establish that judicially, the rights consequent thereon need not be specially asserted or determined, for they flow naturally from the status itself. By narrowing the dispute to the sole point in issue, speed and economy as well as certainty are achieved.

It is perhaps unnecessary to say that mere doubt as to one's status, without evidence of the necessity for a determination and without a

${ }^{12} \operatorname{Re}$ Toronto General Trusts Corp. and Crowley, [1928] 4 D. L. R. (Ont.) 609.

${ }^{203}$ In re Caldicot and Wentlooge Act, 1884, Eton College v. Commissioners of Sewers, [1920] 2 Ch. 463.

${ }_{123}$ Attorney-General v. Parr, [1920] 1 Ch. 339 (powers of defendant trustees under charitable trust); Iiv re Craven Settled Estates, [1926] Ch. 985. 
defendant having an adverse interest, presents an insufficient ground for invoking a judicial declaration. ${ }^{128}$

Yet where personal rights or property rights of sufficient importance to warrant judicial clarification are in the court's opinion involved in an adversary proceeding, the determination of the issue usually serves a useful social purpose and will not be refused. A child was permitted in Wisconsin to sue for a declaration that she was the lawful child of her father's common law marringe, after the father had gone to another state, married another woman, and raised a second family, the second wife having denied the plaintiff's paternity after the father's death. ${ }^{129}$ Need for such relief is so common that in England the Legitimacy Declaration Act of 1858 was passed ${ }^{130}$ and on the Continent statutes authorizing a declaration of legitimacy have been enacted in nearly all countries. The declaration of paternity involved in the grant of a petition for maintenance and support bears some relation to this procedure.

Somewhat unusual in this country is a suit by a daughter against her mother to establish the fact that she is an illegitimate daughter of the defendant. ${ }^{131}$ The demand was justified on the ground that the plaintiff could thereby establish her claim to membership in certain organizations in which early ancestry was a sine qua non and also that she had an interest in remainder after the defendant's life estate. A dissenting judge thought the plaintiff's interest insufficient to sustain the declaration. In the same general category are cases in which a putative father seeks a declaration that an alleged child is not his. ${ }^{132}$

Actions for the declaration of the existence of the plaintiff's marriage with the defendant, requested directly ${ }^{133}$ or indirectly by asking a

${ }^{123}$ Ex parte Eubanks, 202 N. C. 357, 162 S. E. 769 (1932) (Plaintiff, threefourths white and one-fourth Indian, sought declaration that he was not an Indian. He claimed that declaration would relieve him of embarrassment, but cited no defendant. Jurisdiction demied).

${ }^{123}$ Miller v. Currie, 208 Wis. 199, 242 N. W. 570 (1932).

${ }^{100} 21$ \& 22 VICT. c. 93; Beresford v. Att'y-Gen'1, [1918] P. 33. More recent legislation is contained in the Legitimacy Act, $16 \& 17 \mathrm{GEo}$. V; c. 60 (1926), and the Supreme Court of Judicature (Consolidation) Act, 15 \& 16 GEo. V, c. 49 (1925) $\$ 188(1)$.

${ }_{131}$ Morecroft v. Taylor, 225 App. Div. 562, 234 N. Y. Supp. 2 (1st Dep't 1929). In RG. 102, 358 (1921), the German Supreme Court concluded that there was not sufficient legal interest as between an illegitimate child and its mother to justify a declaration of illegitimacy. As against the father, there was such an interest because of the right of maintenance.

${ }_{132}$ Yool v. Ewing, [1904] 1 Ir. R. 434 (declaration denied on jurisdictional grounds) ; Burman v. Burman, [1930] Scot. S.C. (Ct. Sess.) 262.

${ }_{133}$ Muir v. Glasgow Corp., [1917] 2 Scot. L. T. 106 (Plaintiff sought declarator that she was the wife of $X$-defendants being $X$; s brothers. Heard on the right of $X$ 's executor and the Corporation of Glasgow to be joined as defendants, because of plaintiff's possible right to damages for $X^{\prime \prime}$ s death in the course of his employment); Lindsay v. Lindsay, [1927] Scot. S. C. (Ct. Sess.) 395; Dunn v. Dunn's 'Trustees, [1930] Scot. S. C. (Ct. Sess.) 131; Hendry v. Lord Advocate, [1930] Scot. S. C. (Ct. J.) 1027. 
declaration of the nullity of the other spouse's divorce ${ }^{134}$ or asking, a declaration of the nullity of the plaintiff's marriage with defendant, ${ }^{135}$ are quite common. Special statutes in many jurisdictions authorize this kind of proceeding. In a German case, the Supreme Court decided that a plaintiff had a sufficient legal interest in a declaration that her Czechoslovakian divorce was effective in Germany, since her ex-husband had denied its effectiveness there. ${ }^{136}$

Persons desiring to secure their property against confiscation or to establish their rights to other ends have placed in issue the single fact upon which their loss or disadvantage depended, namely, their nationality. ${ }^{137}$ So, those desiring to prevent their ouster as members of societies or organizations have placed in issue their status as members, which often involved merely the question whether the procedure to oust them was proper ${ }^{138}$ or the disqualification alleged against them actually existed. ${ }^{139}$

The obligations of parties to a dispute with respect to property may be put to the test by placing in issue their respective status. Thus, in Nova Scotia a public building which had been built by cooperation of a town and municipality had been partly destroyed by fire. A dispute having arisen as to the municipality's duty to contribute to the cost of repairs, the town sued for a declaration that the municipality had the status of a joint tenant or tenant in common with the plaintiff. ${ }^{140}$ The question whether defendant was obliged to contribute was answered automatically by the determination of its status or relation to the plaintiff.

${ }^{134}$ Baumann v. Baumann, supra note 75 (plaintiff spouse who had not been served with process in the Mexican divorce sought declarations establishing the continued validity of the first marriage and the invalidity of the divorce and second marriage).

${ }^{135}$ Courtin v. Elder, [1930] Scot. S. C. (Ct. Sess.) 68; Cox v. Cox, 13 Alta. L. R. 285 (1918).

ivo RG. 109, 383 (Jan. 5, 1925).

${ }^{137}$ Stoeck v. Public Trustee, [1921] 2 Ch. 67 (plaintiff sought declaration that he was not a German national on Jan. 10, 1920, the crucial date for confiscation of German-owned property in England); Baron Reitzes de Marienwert v. Administrator of Austrian Property, [1924] 2 Ch. 282 (plaintiff claimed alternative declaration as to nationality, for purpose of exempting his property from expropriation).

${ }^{233}$ Jones v. Stott, [1910] 1 K. B. 893 (declaration of continued membership sought); Weinberger v. Inglis (No. 2), [1918] $1 \mathrm{Ch} .517$ (plaintiff sought declarations establishing improper ouster from Stock Exchange, on grounds of improper hearing and his alleged German origin); McLuskey v. Cole, [1922] $1 \mathrm{Ch} .7$; Spencer v. Kennedy, [1926] Ch. 125.

${ }_{1=0}$ Holden v. Southwark Corp., [1921] $1 \mathrm{Ch}$. 550 (officer sought declaration that resolution ousting him was invalid; case turned on whether officer's contracts were of type forbidden under statute); Reynolds v. Shipping Federation, [1924] 1 Ch. 28.

${ }_{140}$ Town of Lunenburg v. Municipality of Lunenburg, [1932] 1 D.L.R. (Nova Scotia) 386 ; cf. Stevens v. Skidmore, [1931] 3 D. L. R. 455, aff'g [1931] 2 D. L. R. (Ont.) 467 '(like issue between private individuals). 


\section{Conclusion}

This survey of certain types of cases in which the need for security in legal relations impels recourse to judicial relief will have indicated the unique function performed by the declaratory judgment. The settlement of disputed issues at their earliest manifestation, before loss and destruction have occurred consequent upon a hazardous gamble or guess as to one's rights, is thereby achieved. Adverse claims of defendants calculated to injure the plaintiff or hamper his freedom of action and peace are determinable when first asserted and, if invalid, are removed, by mere declaration, as clouds upon the plaintiff's rights. As the United States Supreme Court has recently said:

"As the prayer for relief by injunction is not a necessary prerequisite to the exercise of judicial power, allegations of threatened irreparable injury which are material only if an injunction is asked, may likewise be dispensed with if, in other respects, the controversy is, as in this case, rcal and substantial."

The unsettling effects of the existing crisis upon established legal relations, contractual and statutory, are likely to generate doubt, uncertainty, and dispute on every hand. An easy and inexpensive method of removing these disturbances and achieving security becomes indispensable. Whether the plaintiff asserts his right to escape an obligation or his right to hold the defendant to his duties, the action for a declaration of rights affords a speedy method of judicial relief from the uncertainty and insecurity attending times like these. War, fire, or other unanticipated disaster have been common causes unsettling legal relations in the past. Economic disturbances, new legislation, or new developments are as likely to cause changes of circumstances in the future. The very speed of modern life acting upon established relations requires judicial machinery promptly to gauge and determine the effect of the resulting changes upon the status quo. In the declaratory judgment, that machinery is made available and social and individual peace and stability are thereby promoted.

EDWIN M. BORCHARD

YALE SchoOL OF LAw

${ }^{141}$ Nashville, Chattanooga \& St. Louis Ry. v. Wallace, supra note 4, at 348. 